\title{
The Cova des Pas de Vallgornera (Llucmajor, Mallorca): a singular deposit bearing an exceptional well preserved Early Pleistocene vertebrate fauna
}

\author{
Pere Bover*1,2,3, Alex Valenzuela ${ }^{1}$, Carmen Guerra ${ }^{1}$, Juan Rofes ${ }^{4,5}$, Josep A. Alcover ${ }^{1,3}$, \\ Joaquín Ginés ${ }^{6}$, Joan J. Fornós ${ }^{7}$, Gloria Cuenca-Bescós ${ }^{5}$, and Antoni Merino ${ }^{8}$ \\ ${ }^{1}$ Department of Biodiversity and Conservation, Institut Mediterrani d'Estudis Avançats (IMEDEA, CSIC-UIB), Cr. Miquel Marquès 21, 07190 Esporles, \\ Illes Balears, Spain \\ ${ }^{2}$ Australian Centre for Ancient DNA, University of Adelaide, North Terrace Campus, Adelaide, Australia \\ ${ }^{3}$ Research Associate, Mammalogy Department/Division of Vertebrate Zoology, American Museum of Natural History, New York, USA \\ ${ }^{4}$ Departamento de Estratigrafia y Paleontología, Facultad de Ciencia y Tecnología, Universidad del País Vasco, Sarriena s/n, 48940 Leioa, Spain \\ ${ }^{5}$ Grupo Aragosaurus-IUCA, Área de Paleontología, Departamento de Ciencias de la Tierra, Universidad de Zaragoza, 50009 Zaragoza, Spain \\ ${ }^{6}$ Federació Balear d'Espeleologia, Palma, Illes Balears, Spain \\ ${ }^{7}$ Departament de Ciències de la Terra, Universitat de les Illes Balears, Ctra. Valldemossa km 7,5, 07122 Palma, Illes Balears, Spain \\ ${ }^{8}$ Grup Espeleològic de Llubí, Illes Balears, Spain
}

\begin{abstract}
The Cova des Pas de Vallgornera is the longest cave of Mallorca (Balearic Islands, Western Mediterranean) and one of the 30 longest caves in the world. The exploration of one of the galleries allowed the discovery of a fossiliferous deposit of vertebrate remains in a remarkable preservation state. The fossil faunal complex found in this gallery is composed of up to 5 mammalian species (Myotragus aff. kopperi, Hypnomys onicensis, Nesiotites aff. ponsi, Rhinolophus aff. mehelyi and Pipistrellus sp.), at least 14 bird species (among them two Mallorcan endemic taxa: Pica mourerae and Athene vallgornerensis), one reptile (Podarcis aff. lilfordi) and one amphibian (Discoglossus sp.). This faunal composition is similar to the one recorded in the Pedrera de s'Ònix, a well known deposit from the Early Pleistocene of Mallorca, and shared morphological characteristics between taxa of both deposits suggest that the chronology of the Cova des Pas de Vallgornera should be considered Early Pleistocene as well. Both taxonomical analysis and chronology of this fauna furnished information on some speleological aspects of the cave.
\end{abstract}

Keywords: $\quad$ paleontological deposit; Early Pleistocene; Cova des Pas de Vallgornera; Mallorca; fossil vertebrates

Received 26 September 2013; Revised 13 January 2014; Accepted 4 March 2014

Citation: Bover P., Valenzuela A., Guerra C., Rofes J., Alcover J.A., Ginés J., Fornós J.J., Cuenca-Bescós G. and Merino A., 2014. The Cova des Pas de Vallgornera (Llucmajor, Mallorca): a singular deposit bearing an exceptional well preserved Early Pleistocene vertebrate fauna. International Journal of Speleology, 43 (2), 175-192. Tampa, FL (USA) ISSN 0392-6672 http://dx.doi.org/10.5038/1827-806X.43.2.6

\section{INTRODUCTION}

The Balearic Islands are an archipelago located at the western area of the Mediterranean Sea (Fig. 1 A-B). It is compound of two different groups of islands. The Western set, or Pityusic Islands, consists of two main islands (Eivissa ["Ibiza"] and Formentera). On the other hand the Eastern set, or Gymnesic Islands, is more isolated than the Pityusics and constitutes of two main islands (Mallorca and Menorca). The current isolation of the Balearic Islands began at the end of the Messinian Salinity Crisis (MSC), 5.35 My ago (Gautier et al., 1994; Clauzon et al., 1996; Krijgsman et al., 1999).

The existence of abundant caves all around Mallorca is favoured by the geological characteristics of the island, mainly composed of limestones. More than 2,000 caves have been explored and surveyed in the island (Encinas, 2006). Exploration and paleontological excavation in some of these Balearic caves have allowed the discovery and subsequent study and analysis of the fossil fauna from these islands.

Different faunal assemblages have been identified in Mallorca, but the most relevant insular fauna has been recorded in post-Messinian deposits (e.g., Alcover et al., 1981). This faunal assemblage (called Myotragusfauna) is mainly composed of an artiodactyl, Myotragus (Bovidae) (Bate, 1909), a rodent, Hypnomys (Gliridae) (Bate, 1918) and an insectivore, Nesiotites (Soricidae) (Bate, 1944). Although these three taxa survived during 
all the Plio-Pleistocene, recent discoveries prove that other mammalian species colonized Mallorca during the Messinian, and that they became extinct during the Pliocene and Early Pleistocene (Bover et al., 2014, and references therein).

In 1968, a cave known since then as Cova des Pas de Vallgornera, and located on the southern coast of Mallorca, at the municipality of Llucmajor, was discovered in the course of a drilling carried out for the construction of a cesspit.

After the initial exploration of the cave (Collignon, 1982), a first detailed topographic survey published by Merino (1993) represents a cave with a total length of approximately $2 \mathrm{~km}$. After the negotiation of two narrow passages in 1994 and 2004, the length of the cave has been remarkably increased reaching $6.5 \mathrm{~km}$ in 2000 (Merino, 2000), $23 \mathrm{~km}$ in 2006 (Merino et al., 2006), $40 \mathrm{~km}$ in 2007 (Merino et al., 2007), $56 \mathrm{~km}$ in 2008 (Merino et al., 2008), 62 km in 2009 (Gràcia et al., 2009; Merino et al., 2009) and $65 \mathrm{~km}$ in 2011 (Merino et al., 2011). Currently, more than $74 \mathrm{~km}$ have been already surveyed (Merino et al., 2014) and it is considered one of the 30 longest caves in the world (Fig. 1 C). Currently, this cave is only accessible through the artificial entrance excavated in 1968.

The Cova des Pas de Vallgornera (from now on CPV) is an extensive maze cave partially drowned by brackish phreatic waters and it lies in a tabular platform built up by an Upper Miocene reefal limestone sequence (Ginés et al., 2008; Fornós et al., 2010a, 2011, and references there in). It has emerged as a conspicuous coastal cave-system that allows to investigate complex speleogenetic mechanisms and speleothem formation processes, many of them controlled by Quaternary sea level changes (e.g., Ginés et al., 2009a, 2009b; Merino et al., 2009; Tuccimei et al., 2009; Dorale et al., 2010; Fornós et al., 2010a, 2011; Merino \& Fornós, 2010). In this paper we present the fossil faunal assemblage that has been recorded through a single excavation campaign carried out during May 2010 at CPV. The bones collected in the fossiliferous deposit provided relevant information on the collapse of the ancient natural entrance. Additionally, faunal remains also shed light on some other aspects on the geomorphological history of the cave and its chronology.

\section{METHODS}

The short time available for the excavation of the deposit and the complexity of the whole excavation in such a remote place of the cave precluded the use of grid squares to locate the bones in the deposit. Additionally, the main objective of the excavation was to remove the material from the surface, a rescue of material for its conservation and scientific study. Therefore, the collected material was reported on a detailed topographical survey of the passage based on landmarks of the topography and each collected item has been refered to its proximity to one of the 28 established sections (Fig. 1 D, T1-T28). The excavation was mainly collecting bones by hand, although the material partially covered by flowstone had to be

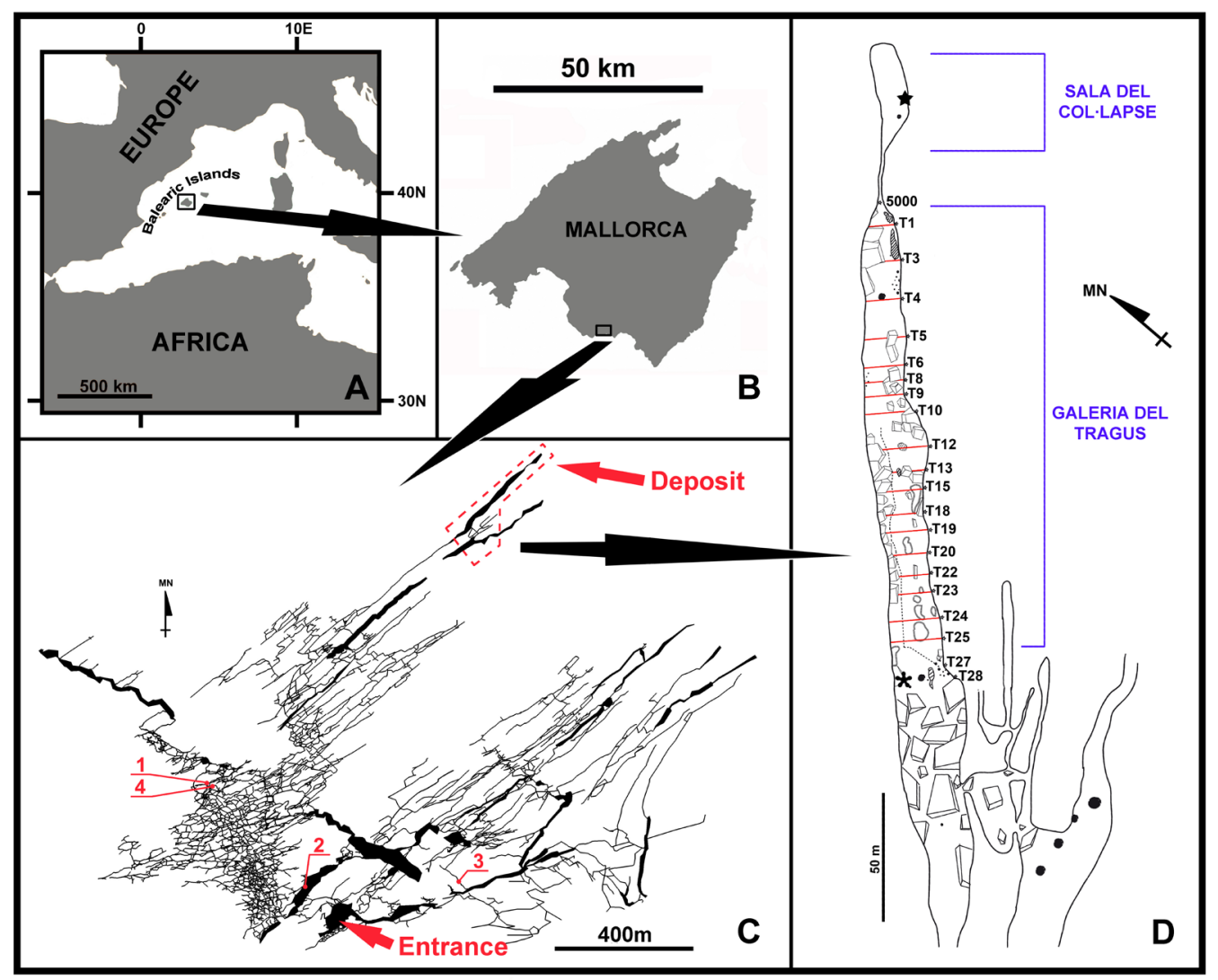

Fig. 1. Map of the Western Mediterranean, with A: the location of the Balearic Islands, and, B: the location of CPV in the island of Mallorca. $\mathrm{C}$ : Schematic topographic survey of CPV, indicating the presence of complete/articulated skeletons of fossil vertebrates mentioned in the text (1. Myotragus, 2-4. Hypnomys sp.), and the location of the current entrance to the cave and the deposit. D: Detailed topographic survey of the Galeria del Tragus/Sala del Col-lapse. Topography landmarks (5000, and location of section T1 to T28) were used to locate the fossil material in the deposit. Asterisk close to T28 indicates the location of the two associated skeletons of Myotragus juveniles, whereas the star in the Sala del Colllapse indicates the location of the articulated Myotragus skeleton (IMEDEA 103003). 
removed using mechanical techniques (Fig. 2.A). After labelling and packaging, the materials were placed in protected containers and carried outside the cave once every day by volunteers. All bones were initially cleaned with water without any kind of aggressive mechanical tool or chemical treatment. A professional conservator (Mr Bernat Font, St Llorenç, Mallorca) worked on a selection of bones that were embebed in hard sediment and/or flowstone, or fragmented. The cleaning of bones was done basically through a mechanical work, although when necessary it was done through a chemically controlled process (see Diaz et al., 2014).

The material from CPV and from other deposits used in this paper as comparison material is listed in Annex 1 (http://dx.doi.org/10.5038/1827-806X.43.2.6). See Díaz et al. (2014) for a complete list of the obtained bones from CPV during the excavation.

The nomenclature used for the teeth is as follows: lowercase letters (' $m$ ' for molar, ' $p$ ' for premolar, and ' $i$ ' for incisor) for lower teeth, and uppercase letters ('M', 'P') for upper teeth. The number after the letter is the position that the tooth occupies in the mandible or maxilla.

Measurements of bones have been taken with a digital caliper ( $0.02 \mathrm{~mm}$ accuracy). Metric values for the Nesiotites bones were recorded using a stereomicroscope (Olympus MSZH, objective 64x) connected to a video camera. We followed Reumer (1984) for measurements, with some additions from Rabeder (1972). For the morphometric analysis we used the PAST v2.01 statistical programme (Hammer et al., 2001).

Measurements abbreviations are as follows: $\mathrm{H}$ : mandible height; $\mathrm{HC}$ : condyle height; Hi: heigth of i1; Hm1: height of mandibular ramus under $\mathrm{m} 1$, in medial view; Hm2: height of mandibular ramus under $\mathrm{m} 2$, in medial view; L: length of the jaw measured from $\mathrm{P}$ point to the mental foramen; Li: length of $\mathrm{i} 1$; Lm1: length of $\mathrm{m} 1$; Lm3: length of $\mathrm{m} 1$; Lm1-m3: m1m3 length; Lp3: length of p3; Lp4: length of p4; Ltr: length of lower toothrow; LLF: length of the lower facet of the condyle; LUF: length of the upper facet of the condyle; TAWm 1: width of $\mathrm{m} 1$ talonid; TRWm 1: width of $\mathrm{m} 1$ trigonid; WC: condyle width; Wm3: width of $\mathrm{m} 3$; Wp4: width of $\mathrm{p} 4$.

In the case of the bovid Myotragus, as the teeth measurements can be influenced by the wear pattern, the measurements were taken at the base of the teeth, but also at $1 \mathrm{~cm}$ from the base to be compared with published data (see text and figure captions for further explanation).

Other used abbreviations: CPV: Cova des Pas de Vallgornera; IMEDEA: Institut Mediterrani d'Estudis Avançats (CSIC-UIB); FBE: Federació Balear d'Espeleologia (Balearic Federation of Speleology); ACAD: Australian Centre for Ancient DNA; MNIBSHNB: Museu de la Naturalesa de les Illes Balears - Societat d'Història Natural de les Balears.

\section{SITE DESCRIPTION}

\section{Geological background}

The cave is located at the southern coast of Mallorca, a region called Migjorn. Upper Miocene tabular deposits outcrop all along the southern and eastern coast, shaping this flat karst region (Fornós \& Gelabert, 2004). This region must be considered as a post-orogenic carbonate platform that discordantly onlaps the folded Mesozoic basement (Serres de Llevant and Serres Centrals). From a sedimentological point of view, the Upper Miocene deposits constitute a complex reef sequence related to the well-differentiated depositional environments characteristics of tropical carbonate platforms, with a wide textural variability as a function of the reef architecture related to the sea level oscillations and the resulting depositional environments (Pomar et al., 1996). This sedimentological complexity produces sharp lateral and vertical changes of rock facies, which have clear repercussions on the pattern and morphology of the cave. Three main units can be distinguished within the Upper Miocene deposits following Fornós et al. (2002): the basal one known as calcisiltites with Heterostegina unit (lower Tortonian in age), the reef complex whose age is Upper TortonianLower Messinian and finally, the Santanyí limestones (also called Terminal Complex) corresponding to the Messinian. CPV is fully developed in the carbonate rocks appertaining to the reef complex (Fornós et al., 2002) being possible to observe, throughout the morphology of its chambers and galleries, the different facies that can be individualised within this unit (Ginés et al., 2008, 2009b, 2014).

\section{Deposit}

CPV is an extensive maze cave whose development surpasses $74 \mathrm{~km}$ of passages and chambers disposed in two principal tiers regarding its elevation (Merino et al., 2011). The main fossiliferous deposit is located at the end of the northernmost passage called Galeria del Tragus with a length of nearly $300 \mathrm{~m}$, mean width of $10 \mathrm{~m}$ and height of $10 \mathrm{~m}$ (see Fig. $1 \mathrm{D}$ ), which is situated in the Sector Descobriments 2004 (Merino et al., 2006). The rectilinear passage hosting the paleontological deposit runs in southwest-northeast direction and in its first 230 meters it is a wide and high gallery with blocks. At the beginning and end of this part of the gallery important and massive flowstone and speleothems deposits can be observed. A final chamber, the Sala del Collapse (Collapse Hall), accessed through a narrow passage, displays a huge collapse of blocks sealing the alleged former entrance from where the different fossil species recorded in the cave entered.

The presence of a flood paleolevel at +4-5 meters on the wall of the Galeria del Tragus suggests the presence of an ancient water-table drowning this part of the cave, which may have conditioned the emplacement of the fossiliferous deposit.

The fossil material was found mainly on surface and widely spread all over the Galeria del Tragus/ Sala del Collapse (Fig. 2 B). Almost all the bones were in extremely good preservation state, but the bones located in parts of the cave close to walls and speleothemes were partially covered by flowstone.

In the floor of Galeria del Tragus, some naturally produced pits reaching the current water-table 


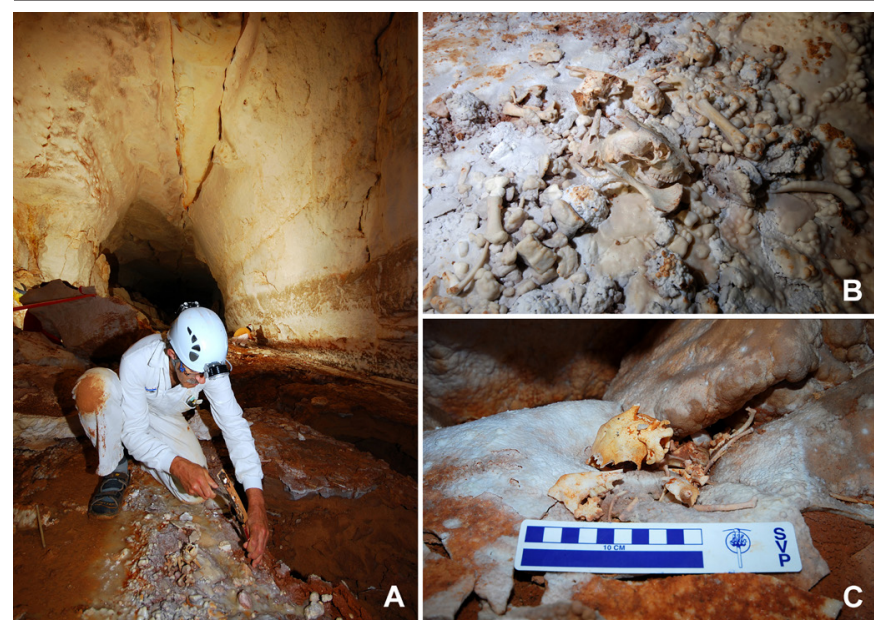

Fig. 2. Excavation of the Galeria del Tragus at CPV. A: Moment of extraction of a bone covered by flowstone. B: Detail of some Myotragus bones in the surface of the deposit. Note that some of them were covered by flowstone. C. Partial skeleton of a juvenile of Myotragus found at the deposit (Photos: M.A. Perelló).

allowed to study the stratigraphy of this zone, and the differences in faunal composition among different layers were analysed (Fornós et al., 2010b).

\section{Excavation remarks}

The fossiliferous deposit is reached after 4 hours of underground trip (including crawling and nearly 1 hour of swimming) from the sole current artificial entrance to the cave (a $6 \mathrm{~m}$ deep man-drilled well). At least two very narrow passages must be negotiated precluding the possibility to carry and use large or heavy equipment in the excavation.

The cave is currently under the protection of Government of the Balearic Islands, and was declared Site of Community Importance, within the Natura 2000 Network by the European Union (European Council Directive 92/43/CEE). The access to the cave is highly restricted and a permit for any research task in the cave must be requested. Moreover, some parts of the cave are specially protected for geological or speleological reasons. The transit across these particular spots is extremely restricted. For this reason, the way to reach the deposit was cautiously selected by the explorers from the FBE to avoid passing through these areas. One of these specially protected sectors, a narrow passage just prior to the Galeria del Tragus with fragile pool crystallizations, was unavoidable. Members of the FBE built a small bridge some weeks prior to excavation, to prevent damaging these formations.

The special protection of the cave and the tough efforts (both physical and in logistics) to reach the deposit forced the excavation team to realize all the work in a single campaign of three days spent inside the cave (28th-30th May 2010).

\section{Stratigraphy}

Fourteen sediment samples were collected in three stratigraphic sections located at the end of the Galeria del Tragus (Fornós et al., 2010b). Sedimentological characteristics were analyzed and stratigraphical data were also recorded.
Sediments sequence in Galeria del Tragus has a thickness of $2.5 \mathrm{~m}$ approximately, but it displays small lateral variations. A complete study of the cave sediments is presented in this volume (Fornós et al., 2014), but it is worth mentioning here that, in general, the sediment sequence observed at the Galeria del Tragus is formed by sands and mud-silts which can be considered allochthonous (entrance facies). This characteristic seems to corroborate the existence of an ancient cave entrance through which sand deposits first, and then sediments infiltrated by surface runoff, entered the cave until the likely closing of it after the collapse of this former entry. The absence of clear lamination and flow structures in the sand deposits of aeolian origin suggest a ramp-type deposition favored by gravity. Nevertheless, the sub-horizontal location of these deposits some hundreds of meters along the gallery seems to indicate a deposition of the whole stratigraphic set in a low dynamic aquatic environment.

The studied sediments sequence shows an evident change in environmental conditions from an arid and probably cold period (prevalence of sands with aeolian origin) to a more humid and probably warm one, during which the increasing of rainfall would have favoured the entry of allochthonus material through surface runoff (Fornós et al., 2010b).

The simplicity of the sequence and the homogeneity of the units seem to indicate that their deposition was produced during a short period of time. This statement is in agreement with the lack of remarkable differences among the fossil remains obtained from the different stratigraphical units.

\section{Chronological remarks}

The chronology of the base of the Quaternary was updated and ratified in 2010 by the International Union of Geological Sciences changing its age from 1.8 My to 2.58 My (Gibbard et al., 2010). In this paper we use the proposed nomenclature according to this updated chronology, mainly for the chronological differentation of "Late Pliocene" (Piacenzian) and "Early Pleistocene" (Gelasian-Calabrian) ranges.

\section{PALEOFAUNAL OVERVIEW}

As a complete analysis of the Pliocene and Pleistocene fauna from the Balearic Islands is beyond the main purpose of the present paper, we will focus on the paleofaunal overview of the island where CPV is located, Mallorca. Further information on the whole fossil faunal framework of the Balearic Islands can be found in Bover et al. (2014) and references therein. The fossil faunal assemblage of the last 5.35 My of the Balearic Islands is composed of the so-called Myotragus-fauna in Mallorca and the Menorcan Pleistocene and by the Nuralagus-fauna in the Menorcan Pliocene (Bover et al., 2008, 2014). In Mallorca, three genera of mammals and a reptile of the original stock that arrived to the island during the Messinian Salinity Crisis (MSC) survived until the Holocene: Myotragus (Bovidae, Cetartiodactyla), Hypnomys (Gliridae, Rodentia), Nesiotites (Soricidae, 
Eulipotyphla), and Podarcis (Lacertidae, Squamata), while a Vipera survived at least until the Late Pliocene. Other terrestrial vertebrates recorded so far in two Mallorcan Early Pliocene deposits, Caló den Rafelino and $\mathrm{Na}$ Burguesa-1, i.e., up to three mammals (a leporid, a cricetid, and a murid), up to eight reptiles (a viperid, a colubrid, a scindid, an anguid, a large lacertid, a gekkonid, a scolecophidian, and a tortoise) (Bailon et al., 2010, 2014; Bover et al., 2007, 2010a, 2014; Quintana et al., 2010; Agustí et al., 2012), have not been recorded in fossil deposits with a post-Early Pliocene chronology of Mallorca.

The preliminary analysis of two Myotragus mandibles from CPV collected in 2009 allowed corroborating the importance of the deposit and establishing a Late Pliocene/Early Pleistocene chronology for the deposit. For this reason, the comparative analysis of the different taxa found in the cave will be focused on the species and fossil material already available from this epoch in Mallorca. Nevertheless, in this section, a general and short overview of the phylogenetic lineages or taxonomic groups present in the Pliocene, Pleistocene and Holocene Mallorcan deposits will be furnished.

\section{Myotragus}

Up to six chronospecies of Myotragus have been identified in Mallorca: M. palomboi from the earlier Early Pliocene (Bover et al., 2010a), M. pepgonellae from the Early-Late Pliocene (Moyà-Solà \& Pons-Moyà, 1982), M. antiquus from the Late Pliocene (Pons-Moyà, 1977), M. kopperi from Early Pleistocene (Moyà-Solà \& PonsMoyà, 1981), M.batei from Early-Middle Pleistocene (Crusafont \& Angel, 1966), and M. balearicus from the Late Pleistocene to Holocene (Bate, 1909).

Some evolutionary changes in the Myotragus lineage have been identified, such as a decrease in body size (through an increase of limb bone robustness and a decrease of bone length, especially in metapodials and stylopodium elements), a progressive reduction of number and size of incisiform and premolar teeth, and the reduction of brain size and sense organs (e.g., Alcover et al., 1981; Köhler \& Moyà-Solà, 2004; Bover $\&$ Tolosa, 2005). Changes in the longevity have been reported in the most recent species, M. balearicus (Köhler \& Moyà-Solà, 2009; Jordana \& Köhler, 2011).

\section{Hypnomys}

Regarding Hypnomys, although remains of this rodent have been obtained from deposits with Early Pliocene chronology (Alcover et al., 1981; Bover et al., 2014) the oldest formally described species is $H$. waldreni, from Late Pliocene deposits (Reumer, 1979). $H$. onicensis, initially described as $H$. intermedius (Reumer, 1981, 1994), from the Early Pleistocene, has been exclusively found in the Mallorcan deposit of Pedrera de s'Ònix (Manacor). The most recent species, H. morpheus, described by Bate (1918), has been recorded in the Middle Pleistocene to Holocene from Mallorca and Menorca.

The most remarkable evolutionary pattern of the lineage is the body size increase and differences among species are mainly related to this characteristic. Another evolutionary trend is the proportional increase of the zygopodium length (Alcover et al., 1981; Bover et al., 2010b).

\section{Nesiotites}

In Mallorca, the shrew genus Nesiotites is represented by three described species, $N$. rafelinensis (earliest Early Pliocene, Rofes et al., 2012, but see also Furió \& Pons-Monjo, 2013 and Rofes et al., 2013), N. ponsi (Late Pliocene, Reumer, 1979) and $N$. hidalgo (Middle Pleistocene to Holocene; Bate, 1944). Additionally, Reumer (1981) described an intermediate form between the last two Mallorcan species, identifying it as $N$. ex. interc ponsi-hidalgo (or $N$. aff. ponsi, according to Alcover et al., 1981), in the Early Pleistocene deposit of Pedrera de s'Ònix (Manacor). This intermediate form from Pedrera de s'Ònix has been reported as indistinguishable from N. meloussae (Pons-Monjo et al., 2010, 2012), a species initially described from the Early Pleistocene of Menorca (Pons-Moyà \& Moyà-Solà, 1980), although this identity remains unclear (e.g., it is not considered by Furió \& Pons-Monjo, 2013).

Evolutionary trends of the genus include the size increase and the loss of the upper fourth unicuspid (in variable proportion of absence of this tooth in Late Pleistocene and Holocene populations; e.g., Reumer, 1980; Alcover et al., 1981; Pons-Monjo et al., 2012; Rofes et al., 2012).

\section{Herpetofauna}

As happens with the fossil mammals, although several endemic species of reptiles and amphibians have been recorded from the Mallorcan Early Pliocene (Bover et al., 2007, 2014; Bailon et al., 2010) belonging to the faunal stock that reached the island during the MSC, just one reptile, Podarcis lilfordi (Lacertidae, Squamata) and one amphibian, Alytes muletensis (Discoglossidae, Anura), survived until Late Pleistocene/Holocene. Both $P$. lilfordi and $A$. muletensis are still currently living in some Mallorcan localities. A Discoglossus (Discoglossidae, Anura) has been also recorded in the Early Pleistocene deposit of Pedrera de s'Ònix, and a Vipera (Viperidae, Squamata) was present at the Late Pliocene.

\section{Birds}

The current knowledge of fossil bird fauna from the Early Pliocene of Mallorca comes from the site of Pedrera de s'Ònix (Mourer-Chauviré et al., 1977, 1980; Alcover et al., 1981; Sondaar et al., 1995; Seguí, 2001). Twenty-seven taxa have been reported at this site, including Tyto balearica, Aegypius cf. monachus, Pica mourerae, and Corvus pliocenus. A mixture of species linked to fresh-water masses and woodlands characterizes this fauna. The Late Pleistocene bird fauna from Mallorca known so far practically not includes species linked to fresh-water masses.

\section{SYSTEMATIC PALEONTOLOGY}

\section{Amphibians}

Three bones (fragmented urostyle, humerus and tibiofibula) belonging to Discoglossus sp. 
(Discoglossidae, Anura) are the sole evidence for the presence of amphibians in the cave. Their morphology fits well with an undescribed species that previously was only known in Mallorca from Pedrera de s'Önix, where it is relatively abundant (Alcover et al., 1981).

\section{Reptiles}

A small lizard has been also recorded in CPV through 12 bones (femora, humeri, jaws, and maxillae), representing at least 4 individuals, two adults and two juveniles. We attribute them to Podarcis aff. lilfordi (Lacertidae, Squamata). All bones are more gracile than in recent Podarcis lilfordi, and agree in size to the lizard present in Pedrera de s'Ònix (Kotsakis, 1981). A complete recovered jaw has 17 teeth, but alveoli for 5 more teeth can be observed.

\section{Birds}

Birds are slightly more abundant in CPV than amphibians and reptiles. Twenty-eight bones have been obtained, belonging to at least 14 species (see Table 1, Fig. 3). A fossil Little Owl has been described from this cave on the basis of two bones (Guerra et al., 2012), including a highly diagnostic tarsometatarsus: Athene vallgornerensis. It has the shortest tarsometatarsus among all the extant and extinct species from its genus in the Western Palearctic. Its shape resembles the Athene angelis tarsometatarsus, although it is markedly smaller. Currently A. vallgornerensis is only known from CPV.

Two bones of large sized vultures are present in the sample of CPV, a proximal fragment of a humerus and a distal fragment of a tibiotarsus (Fig. $3 \mathrm{~A}$ and B). The fragmentary condition of the material does not permit their accurate identification. We attributed the humerus to cf. Gyps, mainly on the basis of the morphology of the crista deltoidea and the morphology of the palmar surface, although the morphology of the pneumatic fossa disagrees with our comparison material of Gyps. The distal fragment of tibiotarsus belongs to Aegypius sp. The Black Vulture has been tentatively reported in Mallorca from Pedrera de s'Ònix (as Aegypius cf. monachus; see Mourer-Chauviré et al., 1977; Alcover et al., 1981). The large-sized Barn Owl Tyto balearica, a species also found in Pedrera de s'Ònix (MourerChauviré et al., 1980), is recorded through a complete ulna (Fig. $3 \mathrm{G}$ ), and a kestrel-like Falcon Falco sp. is represented by two bones (Fig. 3 D-E). The Pleistocene corvid Pica mourerae, described from Pedrera de s'Ònix (Seguí, 2001), has also been identified in CPV (Fig. 3 N-P). Another corvid, Corvus sp., has been herein identified (Fig. 3 Q-S). Its size, as well as the Corvus remains found on other Balearic coeval sites, is smaller than the modern species Corvus corax, although it differs in size from Corvus pliocaenus.

The avian assemblage obtained in the cave does not allow a global approach to the paleoecology from the Late Pliocene/Early Pleistocene of Mallorca, due to the small size of the sample. Nevertheless, the assemblage fits well with that obtained in Pedrera de s'Ònix, despite the latter being slightly more recent. Excepting Athene vallgornerensis, cf. Gyps,
Table 1. Bird species present in CPV. The taxa shared by CPV and Pedrera de s'Ònix (PÒ) are indicated. $\left(^{*}\right) 2$ different Anatidae have been obtained from Pedrera de s'Ònix. $\left.{ }^{* *}\right)$ The species of Corvus found in the Pedrera de s'Ònix is C. pliocaenus. Two of the obtained bird taxa, Pica mourerae and Athene vallgornerensis, have never been found outside Mallorca so far, and thus, they should be considered as endemic species to the island.

\begin{tabular}{|c|c|c|c|c|}
\hline Taxon & $\begin{array}{l}\text { IMEDEA } \\
\text { number }\end{array}$ & Element & $\begin{array}{l}\text { Presence } \\
\text { in PÒ }\end{array}$ & Illustration \\
\hline Anatidae indet. & 91889 & $\begin{array}{l}\text { Right ulna-proximal } \\
\text { fragment }\end{array}$ & $X\left({ }^{*}\right)$ & Fig. 3H \\
\hline Aegypius sp. & 91976 & $\begin{array}{l}\text { Right humerus-condylus } \\
\text { lateralis }\end{array}$ & $\mathrm{x}$ & Fig. 3B \\
\hline cf. Gyps sp. & 94691 & $\begin{array}{l}\text { Right humerus-proximal } \\
\text { fragment }\end{array}$ & - & Fig. $3 \mathrm{~A}$ \\
\hline Accipiter nisus & 91885 & $\begin{array}{l}\text { Right humerus-proximal } \\
\text { fragment }\end{array}$ & $\mathrm{x}$ & Fig. 3C \\
\hline $\begin{array}{l}\text { Falco sp. } \\
\text { (small size) }\end{array}$ & 91884 & $\begin{array}{l}\text { Right tibiotarsus distal } \\
\text { fragment }\end{array}$ & - & Fig. 3E \\
\hline $\begin{array}{l}\text { Falco sp. } \\
\text { (small size) }\end{array}$ & 91955 & Left ulna-distal fragment & - & Fig. 3D \\
\hline Crex sp. & 91887 & $\begin{array}{l}\text { Right ulna-distal and } \\
\text { medial fragment }\end{array}$ & - & Fig. 3I \\
\hline $\begin{array}{l}\text { Scolopax } \\
\text { rusticola }\end{array}$ & 91965 & Left humerus & $x$ & Fig. 3J \\
\hline $\begin{array}{l}\text { Columba } \\
\text { palumbus }\end{array}$ & 91892 & Incomplete left scapula & - & Fig. 3K \\
\hline Tyto balearica & 90468 & Right ulna & $x$ & Fig. $3 G$ \\
\hline $\begin{array}{l}\text { Athene } \\
\text { vallgornerensis }\end{array}$ & 91958 & Right tarsometatarsus & - & Fig. 3F \\
\hline $\begin{array}{l}\text { Athene } \\
\text { vallgornerensis }\end{array}$ & 91897 & Terminal phalan $x$ & - & \\
\hline Pica mourerae & 91966 & Left tarsometatarsus & $\mathrm{x}$ & \\
\hline Pica mourerae & 91967 & Right tarsometatarsus & $\mathrm{x}$ & Fig. 3P \\
\hline Pica mourerae & 91968 & $\begin{array}{l}\text { Left tarsometatarsus- } \\
\text { distal fragment }\end{array}$ & $x$ & Fig. 30 \\
\hline Pica mourerae & 91883 & Right carpometacarpus & $x$ & Fig. $3 \mathrm{~N}$ \\
\hline cf. Corvus & 91891 & Right femur. Juvenile & $X(* *)$ & \\
\hline Corvus sp. & 90470 & Right humerus & $x$ & Fig. $3 Q$ \\
\hline Corvus sp & 90471 & $\begin{array}{l}\text { Fragmented left } \\
\text { tarsometatarsus }\end{array}$ & $x$ & Fig. 3S \\
\hline Corvus sp. & 91898 & $\begin{array}{l}\text { Right carpometacarpus- } \\
\text { distal fragment }\end{array}$ & $x$ & Fig. 3R \\
\hline Corvidae indet. & 91890 & $\begin{array}{l}\text { Left tibiotarsus-distal } \\
\text { and medial fragment }\end{array}$ & $x$ & Fig. $3 \mathrm{M}$ \\
\hline Corvidae indet. & 91969 & $\begin{array}{l}\text { Left coracoid-distal } \\
\text { fragment }\end{array}$ & $x$ & Fig. 3L \\
\hline Turdus sp. & 91895 & Right carpometarcarpus & $\mathrm{x}$ & \\
\hline Turdus sp. & 90469 & Left ulna & $x$ & \\
\hline $\begin{array}{l}\text { Fringillidae } \\
\text { indet }\end{array}$ & 91961 & Incomplete premaxilla & $x$ & \\
\hline $\begin{array}{l}\text { Fringillidae/ } \\
\text { Passeridae }\end{array}$ & 91963 & $\begin{array}{l}\text { Mandible-apical } \\
\text { fragment }\end{array}$ & $x$ & \\
\hline $\begin{array}{l}\text { Passeriformes, } \\
\text { indet }\end{array}$ & 91900 & $\begin{array}{l}\text { Left tarsometatarsus- } \\
\text { distal fragment }\end{array}$ & $\mathrm{x}$ & \\
\hline $\begin{array}{l}\text { Passeriformes, } \\
\text { indet }\end{array}$ & 91956 & $\begin{array}{l}\text { Left tarsometatarsus- } \\
\text { proximal fragment }\end{array}$ & $\mathrm{x}$ & \\
\hline
\end{tabular}

Falco sp., Crex sp. and Columba palumbus, all the taxa recovered in CPV are also present in Pedrera de s'Ònix. The whole fauna fits well with a rocky cliff's avian community in an open shrub environment, with some close water sites. 

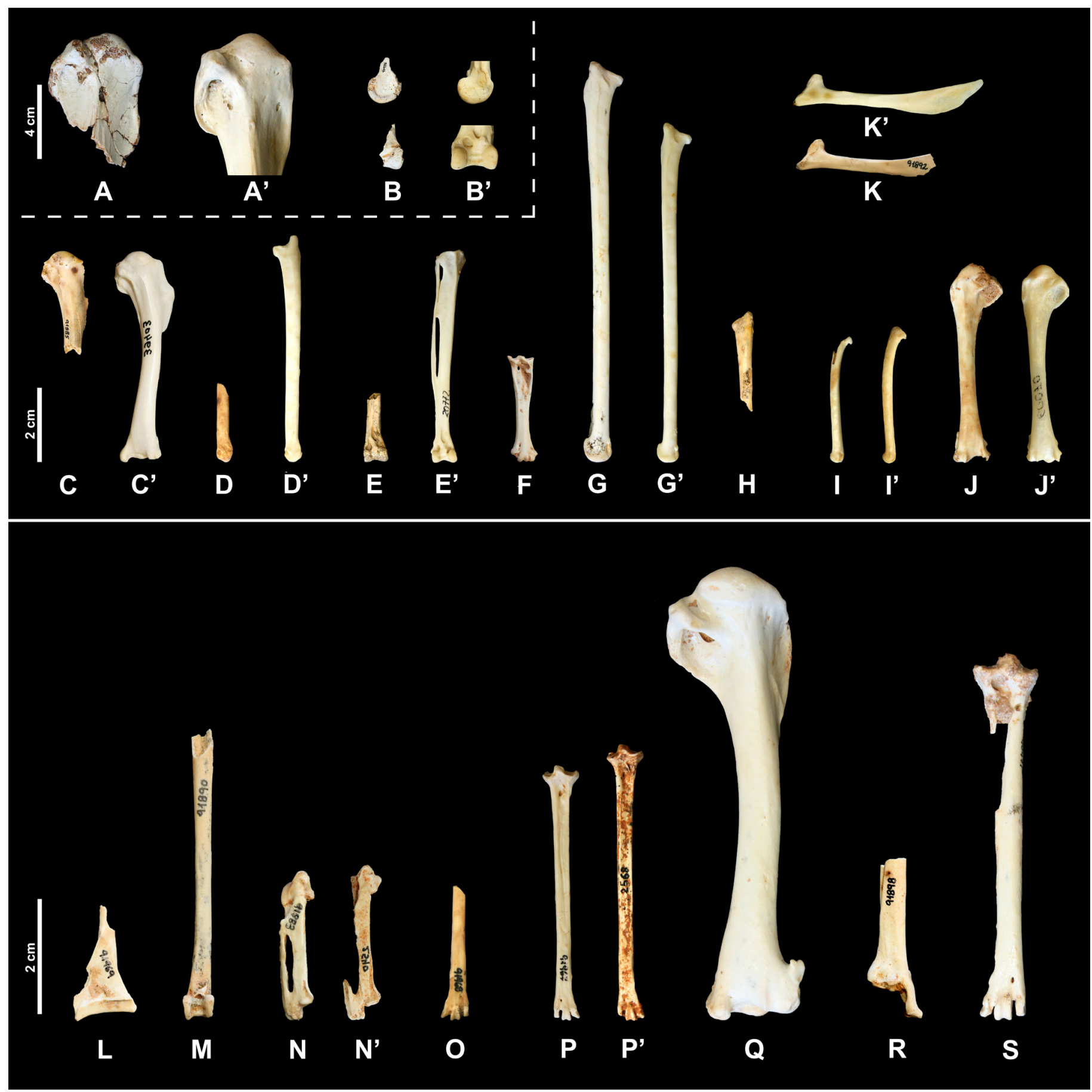

Fig. 3. Bird bones obtained from CPV. Top: Non-Passeriformes from Cova des Pas de Vallgornera (A-K), with comparison material (A'K'). A: IMEDEA 94691, cf Gyps, proximal end of a right humerus, caudal view; A': IMEDEA 60079, Gyps fulvus, proximal end of a right humerus, caudal view; B: IMEDEA 91976, Aegypius sp., distal end of a left tibiotarsus, medial and cranial views; B': IMEDEA 60145, Aegypius monachus, distal end of a left tibiotarsus distal end medial and cranial views; C: IMEDEA 91885, Accipiter nissus, proximal end of a right humerus, caudal view; C': IMEDEA 39403, Accipiter nissus, proximal end of a left humerus, reversed, caudal view; D: IMEDEA 91955, Falco sp., fragmented left ulna, ventral view; D': IMEDEA 20772, Falco tinnunculus, left ulna, ventral view; E: IMEDEA 91884, Falco sp., distal end of a right tibiotarsus, cranial view; E': IMEDEA 20772, Falco tinnunculus, right tibiotarsus, cranial view; F: IMEDEA 91958, Athene vallgornerensis, right tarsometatarsus, cranial view; G: IMEDEA 90468, Tyto balearica, right ulna, ventral view; G': IMEDEA 21884, Tyto alba, right ulna, ventral view; H: IMEDEA 91889, Anatidae, undetermined genus and species, proximal part of a left ulna, ventral view; I: IMEDEA 91887, Crex sp., fragmented left ulna, ventral view; l': IMEDEA 34882, Crex crex, left ulna, ventral view; J: IMEDEA 91965, Scolopax rusticola, left humerus, caudal view; J': IMEDEA 60070, Scolopax rusticola, reversed right humerus, caudal view; K: IMEDEA 91892, Columba palumbus, fragmented left scapula, medial view; K': IMEDEA 20898, Columba palumbus, left scapula, medial view. Bottom: Passeriformes from CPV (L-S), together with Pica mourerae comparison material (N', P'). L: IMEDEA 91969, Corvidae undetermined genus and species, distal fragment of left coracoid, dorsal view; M: IMEDEA 91890, Corvidae undetermined genus and species, fragmented left tibiotarsus, cranial view; N: IMEDEA 91883, Pica mourerae, right carpometacarpus, dorsal view; N': IMEDEA 2540, Pica mourerae, reversed left carpometacarpus, dorsal view, Pedrera de s'Ònix, Mallorca; O: IMEDEA 91968, Pica mourerae, distal part of a left tarsometatarsus, cranial view; P: IMEDEA 91967, Pica mourerae, right tarsometatarsus, cranial view; P': IMEDEA 2568, Pica mourerae, right tarsometatarsus, cranial view, Pedrera de s'Ònix, Mallorca; Q: IMEDEA 90470, Corvus sp., right humerus, caudal view; R: IMEDEA 91898, Corvus sp., distal end of right carpometacarpus, dorsal view; S: IMEDEA 90471, Corvus sp., left tarsometatarsus, cranial view. 


\section{Mammals}

Bones of the three taxa of terrestrial mammals present during all the Late Pliocene to Holocene in Mallorca have been recovered from CPV. Preliminary analysis of the morphological characteristics of these bones (e.g., following Alcover et al., 1981), allows the clear attribution of the obtained material as belonging to Myotragus, Hypnomys and Nesiotites. Thus, the objective of the analysis of the mammalian bones here presented is to identify them to species level. Specifically, the accurate taxonomic attribution of the bones of these three mammalian taxa can furnish an approximate chronological framework to the deposit as the fossil records of these three genera are remarkably complete, especially in the case of Myotragus. Additionally, some fossil remains of bats (Chiroptera) have been also obtained from the cave.

\section{Eulipotyphla}

Up to 30 bones of Nesiotites (Soricidae) have been recovered from CPV (Fig. 4 A). Although postcranial remains of this genus have been recovered, the identification of the different Nesiotites species using these bones is ambiguous. For this reason, in order to evaluate the taxonomical attribution of the species found in CPV a Principal Component Analysis (PCA) with tooth and linear measurements of six mandibles of Nesiotites from CPV (see Annex 1) and the other species from Mallorca has been performed (four mandibles of $N$. ponsi, six of $N$. aff. ponsi and nine of $N$. hidalgo as comparison material; see Rofes et al., 2012 for further information).
In Fig. $4 \mathrm{~B}$, variables $\operatorname{Lm} 1$, TRWm 1 , TAWm 1 , $\mathrm{Hm} 1$, and $\mathrm{Hm} 2$ are included, whereas in Fig. 4.C the variables used are $\mathrm{Li}, \mathrm{Hi}, \operatorname{Lm} 1, \mathrm{TRWm} 1$, TAWm1, Hm1, Hm2, Lm1-m3, L, H, HC, WC, LUF, and LLF.

Both figures show that on PC1 (indicating the variance in size) the specimens are distributed in three main groups (from left to right): a) Farrutx (Nesiotites ponsi, Late Pliocene); b) CPV + Pedrera de s'Ònix (Nesiotites aff. ponsi, Early Pleistocene; c) Cova de Llenaire + Cova Estreta + Cova de Canet (Nesiotites hidalgo, Late Pleistocene/Holocene). On PC2 (indicating mainly morphology), no clear-cut differentiation can be observed.

The distribution of CPV specimens mainly overlaps with the one of $N$. aff ponsi from Pedrera de s'Ònix, especially in Fig. $4 \mathrm{C}$, in which a larger number of variables was obtained. This overlap suggests that the Nesiotites from CPV displays a greater affinity with $N$. aff ponsi than with $N$. ponsi or $N$. hidalgo. Nevertheless, the specimens from Pedrera de s'Ònix are more robust than those from CPV and the coronoid process of the latter specimens lean slightly more lateralwards in posterior view (respect to the mandibular ramus) than those from Pedrera de s'Ònix. Although an unequivocal attribution of the Nesiotites from CPV to $N$. aff. ponsi from Pedrera de s'Ònix cannot be established, they share large number of affinities. We identify here the taxa from CPV as $N$. aff. ponsi, although further analyses and material will be necessary to evaluate its presumably close relationships with the Pedrera de s'Ònix Nesiotites.
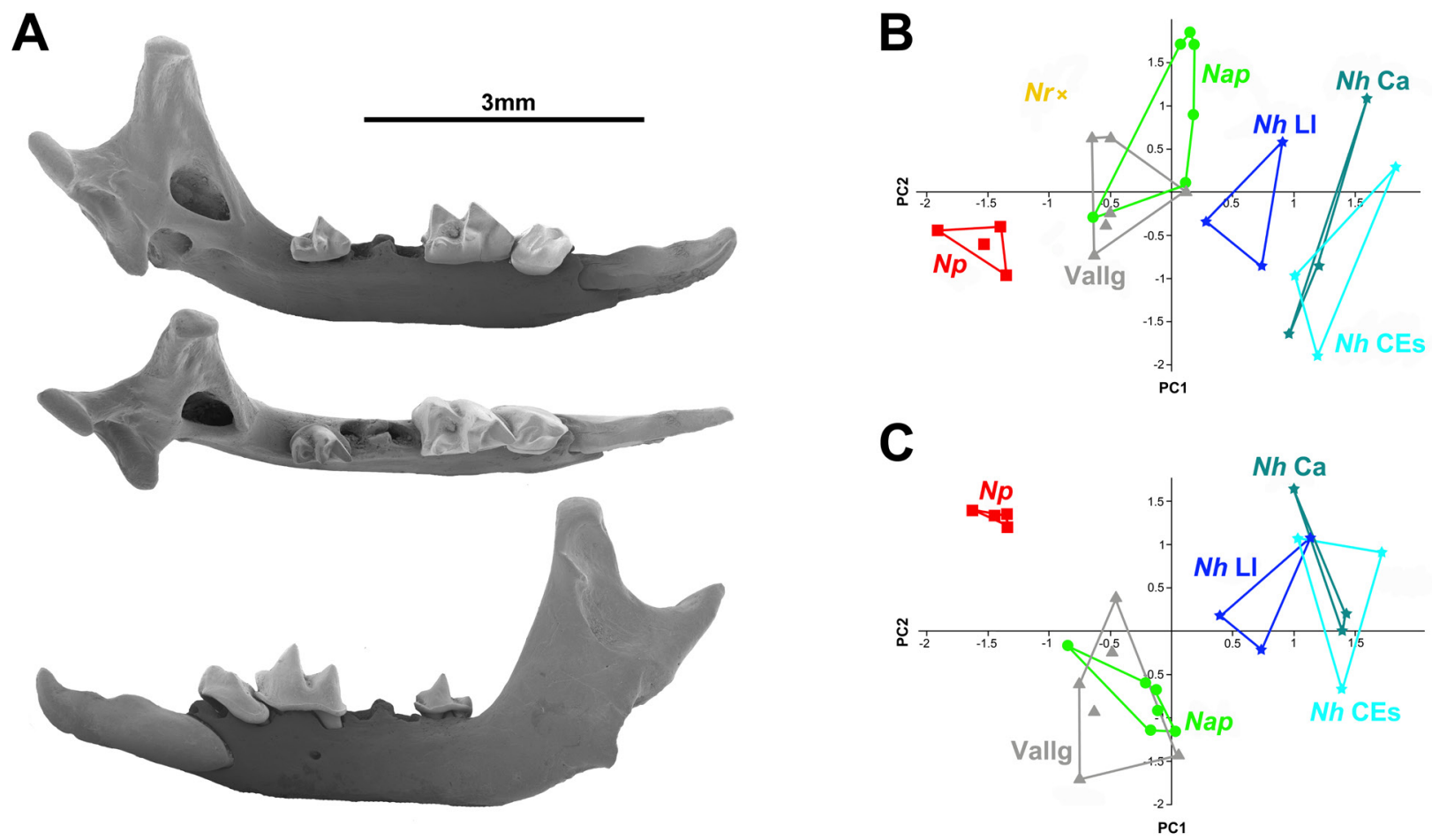

Fig. 4. Analysis of the Nesiotites bones found in CPV. A: SEM photo of left mandible IMEDEA 95073, in lingual (top), occlusal (centre), and labial (bottom) views. Principal Component Analysis (PCA) with tooth and linear measurements of mandibles of several species of Nesiotites using variables Lm1, TRWm1, TAWm1, Hm1, and Hm2 in B, and variables $\mathrm{Li}, \mathrm{Hi}, \mathrm{Lm} 1$, TRWm1, TAWm1, Hm1, Hm2, Lm1-m3, L, H, HC, WC, LUF, and LLF in C. Abbreviations: Nr, N. rafelinensis from Caló den Rafelino. Np, N. ponsi from Crulls de Cap Farrutx. Nap, N. aff. ponsi from Pedrera de s'Önix. Nh LI, N. hidalgo from Cova de Llenaire, Nh Ca, N. hidalgo from Cova de Canet. Nh CEs, N. hidalgo from Cova Estreta. Vallg, Nesiotites aff. ponsi from CPV. 


\section{Rodentia}

Up to 483 bones of Hypnomys (Gliridae) have been recovered from the Galeria del Tragus/Sala del Col-lapse (Fig. 5 A-I). As in Nesiotites, the morphological differences of the postcranial skeleton among the Balearic Hypnomys species are small. Nevertheless, we analysed the size of the long limb bones, and teeth.

Additionally to the material obtained in the Galeria del Tragus/Sala del Col·lapse, at least two articulated skeletons and an unarticulated skeleton of Hypnomys have been found in different parts of the cave, even in places located far from the former entrance of the cave (Fig. 6 B-D), in Llac de na Gemma, Sector Gregal, and Sector F (Fig. 6 B, C, D, and points 2, 3, 4 in Fig. 1 C, respectively).

No data of measurements of limb bones of the older species of Hypnomys have been published and complete specimens of these bones are scarce (personal observation). Mills (1976) published several measurements made on $H$. morpheus long bones. He used long bones lacking one of the epiphyses additionally to complete bones. Thus, the total length of limb bones of Hypnomys from CPV has been compared to those of the scarce complete available material of $H$. onicensis curated at IMEDEA, and to the data published by Mills (1976) and Bover et al. (2010b). The measurements of long limb bones without one of the epiphyses and complete (when available) are furnished in Table 2. Data suggest that no clear distinction among the different species can be established with just postcranial length measurements as the range of measurements of each bone for every species widely overlaps among them.

For this reason, we compared the size of several teeth. As no upper cheek teeth have been obtained in CPV, just data of lower cheek teeth from this cave together with data from bibliography have been used (Reumer, 1979, 1981; Agustí, 1980).

According to Reumer (1981) the ratio width/ length of $\mathrm{p} 4$ and $\mathrm{m} 3$ (Wp4/Lp4 and Wm3/Lm3) seems to discriminate among the different species of Hypnomys, and the scatter plot of this ratio also shows the differences in size of the different species. In Fig. $5 \mathrm{~J}-\mathrm{K}$, ratios $\mathrm{Wp} 4 / \mathrm{Lp} 4$ and $\mathrm{Wm} 3 / \mathrm{Lm} 3$ of Hypnomys from CPV are compared with the obtained for other Hypnomys species by Reumer (1981). Both ratios in
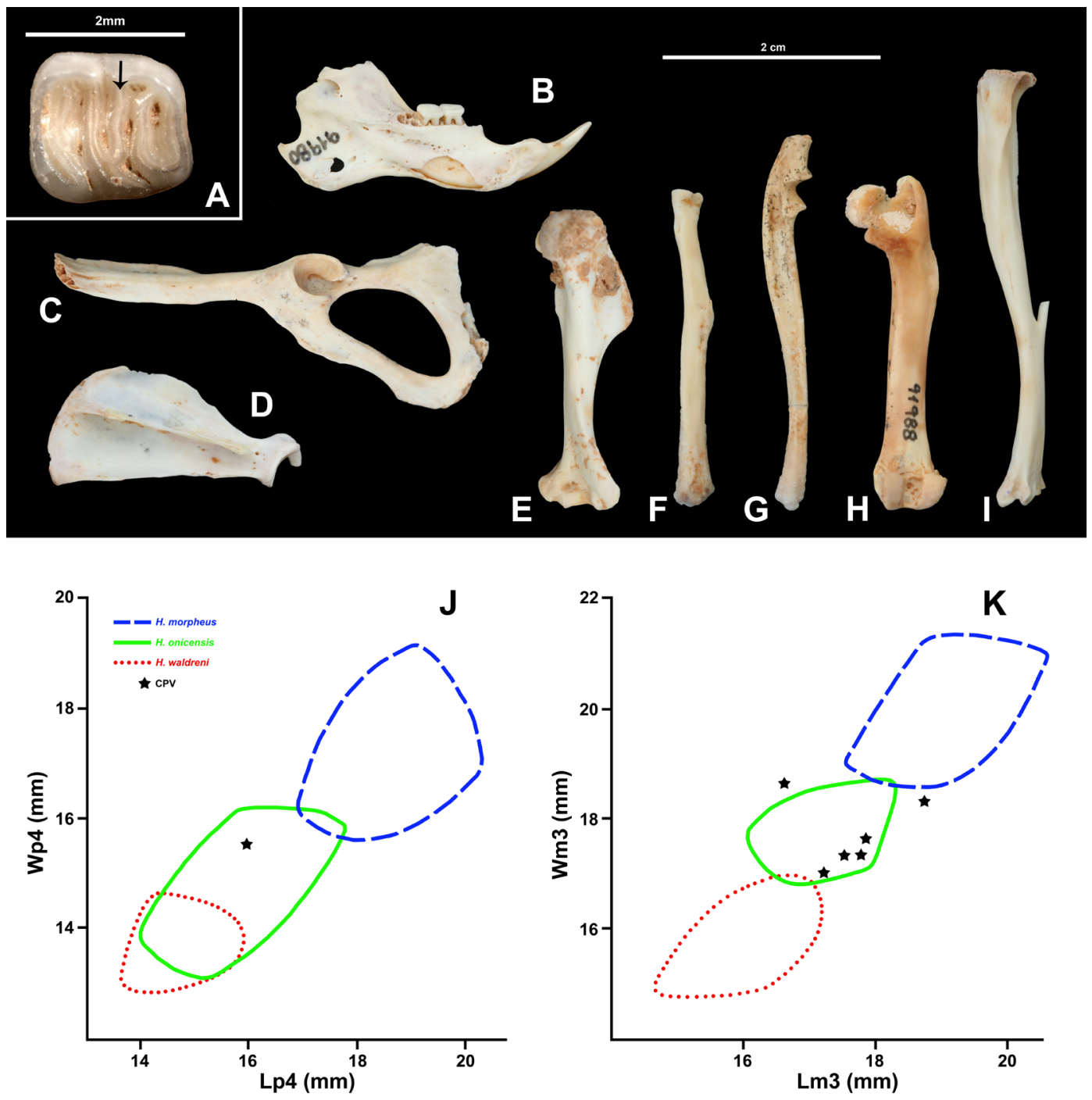

Fig. 5. Hypnomys bones from CPV. A: Detail of the right $\mathrm{m} 1$ of mandible IMEDEA 95117, occlusal view. The arrow indicates a long centrolophid; B: Left mandible IMEDEA 91980, lingual view; C: Left pelvis IMEDEA 95301, lateral view; D: Right scapula IMEDEA 90467, lateral view; E: Right humerus IMEDEA 95152, caudal view; F: Right radius IMEDEA 91984, cranial view; G: Right ulna IMEDEA 95543, lateral view; H: Right femur IMEDEA 91988, caudal view; I: Right tibia IMEDEA 95136, medial view; J-K: Scatter plot of width versus length of p4 and m3 (modified from Reumer, 1981) of different Hypnomys species. New measurements from Hypnomys from CPV are plotted with the data for $H$. waldreni, $H$. onicensis from Pedrera de s'Ònix, and H. morpheus depicted by Reumer. 
Table 2. Mean, range (Max-Min) and number of samples ( $n$ ) of limb bones length measurements (in mm) using Mills (1976) criteria, for bones without one of the epiphysis (partial bones) and complete bones. Vall. Hypnomys onicensis. from CPV; Ho. H. onicensis from Pedrera de s'Ònix. Hm. Hypnomys morpheus from Cova de Muleta (Measurements for $H$. morpheus recalculated from Mills, 1976) and Cova des Coral·loides (Bover et al., 2010b).

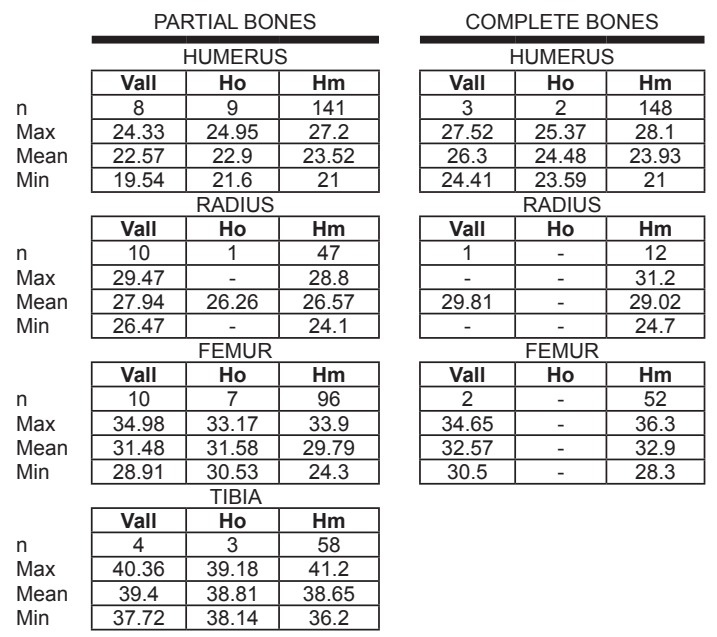

the figure indicate that the size and proportions of the studied teeth of CPV Hypnomys is included within the variability of $H$. onicensis from Pedrera de s'Ònix, and thus, the rodent remains from $\mathrm{CPV}$ can be tentatively atributed to $H$. onicensis.

Agusti (1980) suggested that the presence of a long centrolophid in the $\mathrm{m} 1$ and $\mathrm{m} 2$ of $H$. waldreni is a primitive characteristic, which is not displayed by the more modern species of Hypnomys such as $H$. morpheus and H. eliomyoides. As in Pedrera de s'Ònix (see Reumer, 1981), Hypnomys from CPV displays long centrolophids in $\mathrm{m} 1$ and $\mathrm{m} 2$ (Fig. 5.A).

\section{Chiroptera}

Two species of fossil bats are present in CPV (Fig. 7). The most abundant is a horseshoe bat (Rhinolophus) of middle size, which used the cave as a refuge (Fig. 7 A-D). Currently, three species of middle-sized Rhinolophus inhabit the Mediterranean region: $R$. mehelyi, $R$. euryale (both in the named "euryale-group") and
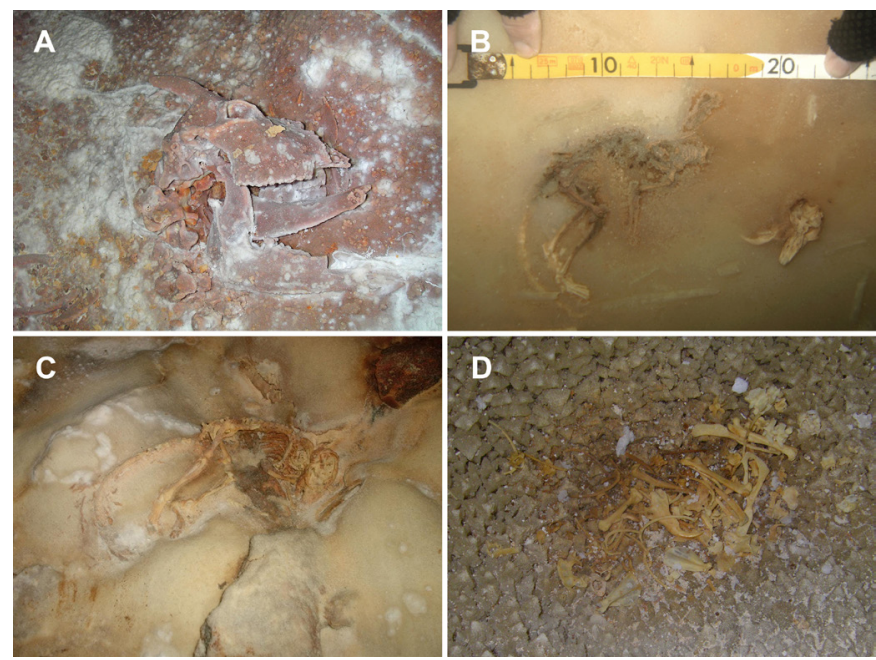

Fig. 6. Associated skeletons found in different places of CPV. A: Myotragus sp. in Sector F; B: Hypnomys sp. in the Llac de na Gemma; C: Hypnomys sp. in Sector de Gregal; D: Hypnomys sp. in Sector F. See Fig. 1 for the location of these skeletons in the cave. Photos: A. Merino, M.A. Perelló, G. Mulet and J.A. Alcover.
R. blasii (in the "landeri-group"; Gábor, 2008). The morphology of the skull and humerus of CPV specimen fits well with the species of euryale group, and differs from the morphology of $R$. blasii, according to the criteria of Felten et al. (1973), Dodelin (2002), and Lindenau (2005). The shape of the distal epiphysis of the humerus, a highly diagnostic trait for the genus, resembles more to $R$. mehelyi than to $R$. euryale. Nevertheless, the bones measurements are slightly smaller than in recent populations of $R$. mehelyi, and are closer to $R$. euryale. Additionally, about 12 fossil species of Rhinolophus have been described in the Western Palearctic (for a summary, see Gunnell et al., 2011). We excluded most of them for comparison, as they are included in the hipposideros and ferrumequinum groups. Rhinolophus neglectus is the sole fossil species of the euryale group, and it should be considered as closely related to $R$. mehelyi (Woloszyn, 1987). This group also includes the fossil subspecies Rhinolophus euryale praeglacialis. $R$. neglectus and $R$. e. praeglacialis are both insufficiently defined (Popov, 2004). Waiting for a review of the group, CPV horseshoe bat is here attributed to $R$. aff. mehelyi. The second bat species present in the cave is a small Pipistrellus represented by two very incomplete specimens (see Fig. 7 E).

\section{Cetartiodactyla}

Around 970 bones of Myotragus (Bovidae) belonging to a minimum number of 38 individuals have been obtained from our excavation of CPV. They correspond to 894 individual bones, a near complete adult associated skeleton and two partial associate juvenile skeletons. The number of recovered femora is remarkably greater than the number of other limb bones, probably related to an unknown taphonomical reason.

Additionally to the scattered bones in the Galeria del Tragus, an almost complete skeleton of Myotragus was found the last day of the excavation in the Sala del Colllapse at a depth of $10 \mathrm{~cm}$. It was located in a corner of this chamber in anatomical position.

Associated partial skeletons of two Myotragus juvenile specimens were found at the beginning of the Galeria del Tragus (Fig. 1 and 2 C). The mandibles of these skeletons display a dp4 completely erupted and $\mathrm{m} 1$ near starting the eruption.

Another complete articulated skeleton of Myotragus was found far away from the Galeria del Tragus, in the passages of the Sector F (Fig. 6 A, and 1 in Fig. 1 C). This skeleton is covered by flowstone, so the risk of breaking the bones during extraction was extremely high, precluding its excavation. Other Myotragus isolated bones, covered with flowstone were found in the biggest chamber of the cave known as Sala Que No Té Nom (Unnamed Hall).

In order to determine the taxonomic identity of the Myotragus remains retrieved from the cave, two main characteristics have been observed, both of them related with teeth morphology in adult individuals: first, number and shape of incisors, and second, relative size of the lower and upper premolars (mainly p2-3, P2-3). Although some skulls of Myotragus from 


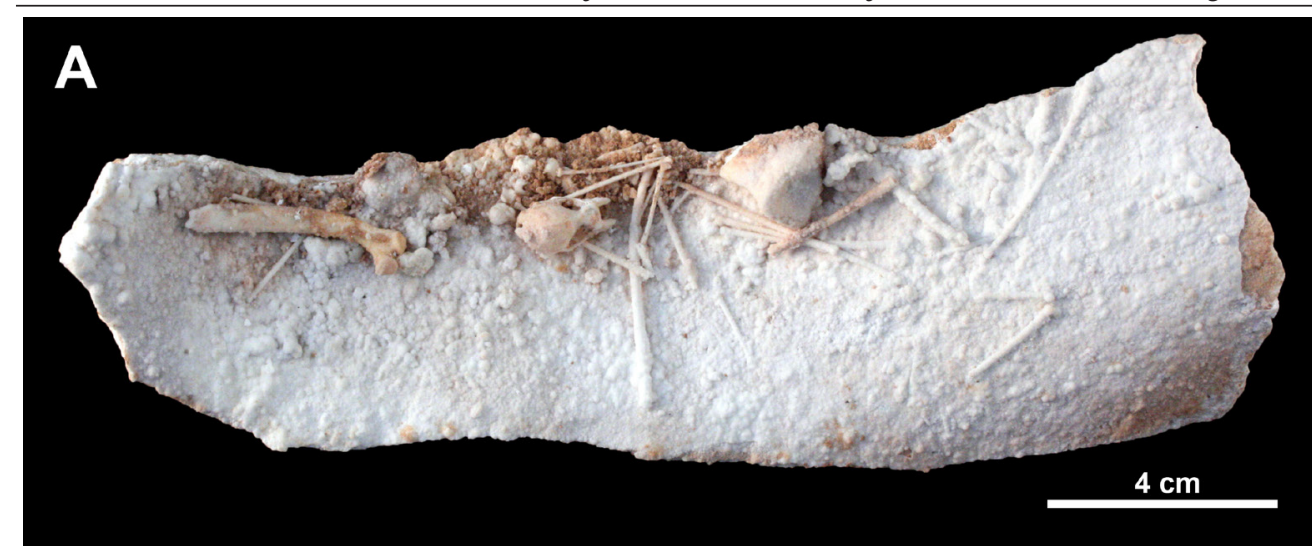

Fig. 7. Bat bones from CPV. A-C:

Specimens of Rhinolophus aff. mehelyi embebed in flowstone. A: IMEDEA 94692, remains of an individual, with a rib of a juvenile Myotragus;

B: IMEDEA 94693, incomplete specimen, with two jaws, a clavicule and several vertebrae; C: IMEDEA 94694, skull; D: Other specimens of Rhinolophus aff. mehelyi. 1: IMEDEA 94695 and 2: IMEDEA 94696, skulls, dorsal and ventral views; 3: IMEDEA 94697, skull, dorsal view; 4: IMEDEA 94698, left jaw, labial view; radius, left humerus, posterior view; 5: IMEDEA

94700, 6: IMEDEA 94704, and
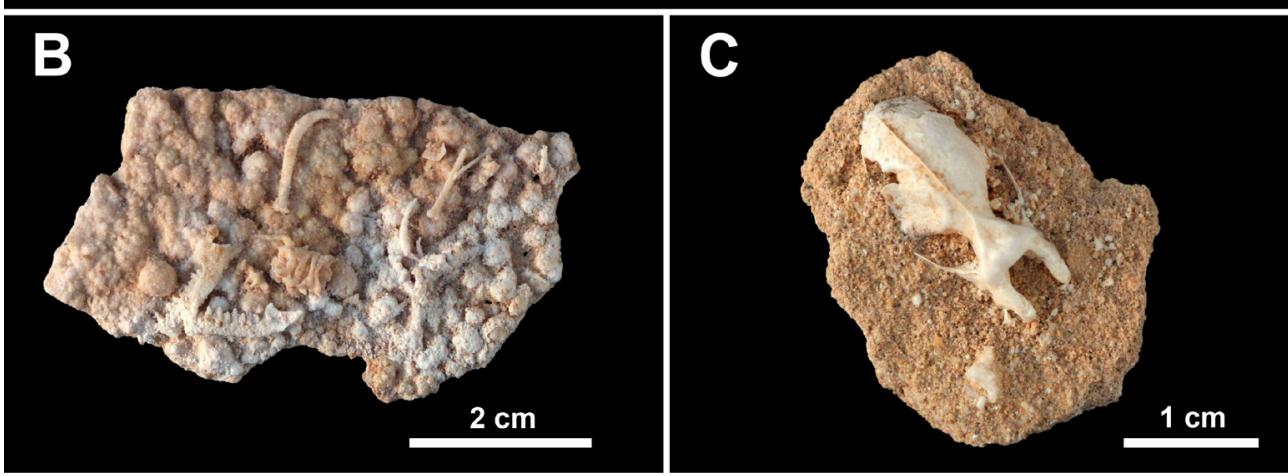

7: IMEDEA 94705, left humeri, posterior view; 8: IMEDEA 94699, 9: IMEDEA 94701, 10: IMEDEA 94706, and 11: IMEDEA 94707, right humeri, posterior view; E: Specimens of Pipistrellus sp. 12: IMEDEA 94715, right jaw, labial view; 13: IMEDEA 94717 and 14: IMEDEA 94718, radii; 15: IMEDEA 94716 and 16: IMEDEA 94719, humeri, posterior view.

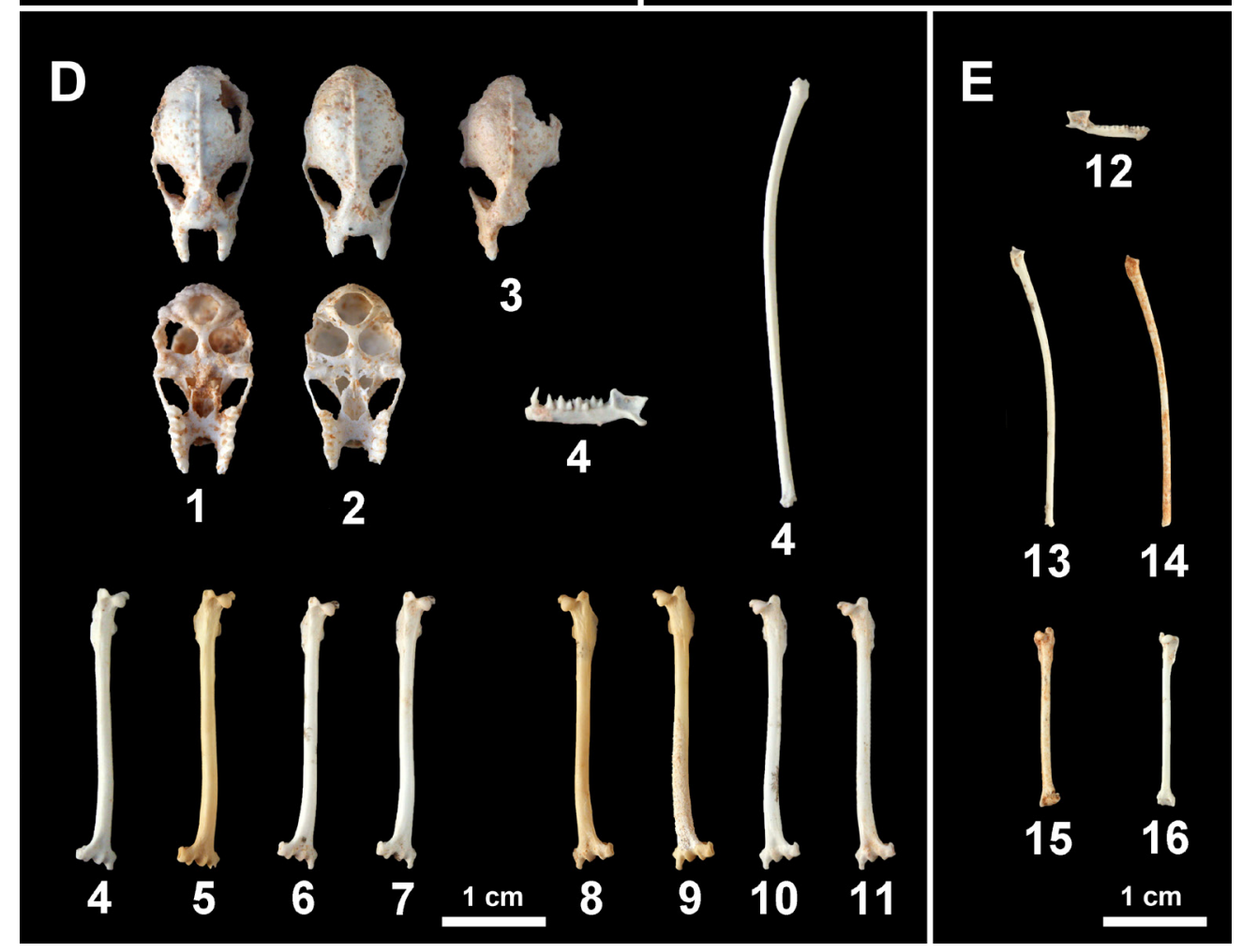

CPV are available, mandibles are more suitable for taxonomical identification and the analysis has been based on this bone.

The number of incisors is a rough indicative of the approximate evolutionary stage of the genus. In this sense, the most recent species, $M$. balearicus, displayed a single evergrowing incisor in each hemimandible (Bate, 1909), while the Early-Late Pliocene species, $M$. pepgonellae had four (Moyà-Solà \& Pons-Moyà, 1982). No complete mandible with incisors is available for the oldest Myotragus species from the Early Pliocene, M. palomboi (Bover et al., 2010a). Between M. pepgonellae and M. balearicus, the other taxa of Myotragus display a progressive reduction of the number of incisors, i.e. three in $M$. antiquus (after Pons-Moyà, 1977) and M. kopperi (Moyà-Solà \& Pons-Moyà, 1981) and two in M. batei. Although the holotype of this latter species displays 3 incisors (Crusafont \& Angel, 1966), in our view, it represents an incompletely grown specimen and it has been considered that the third small incisor (probably the $\mathrm{dI}_{3}$, third deciduous incisor) would be lost later. This same phenomenon has been recorded in some individuals of $M$. balearicus from Late Pleistocene deposits, in which a small distal incisor (or its alveolus) is displayed in juvenile stages, being posteriorly lost in adult ages (see Bover \& Alcover, 1999, and references therein). 


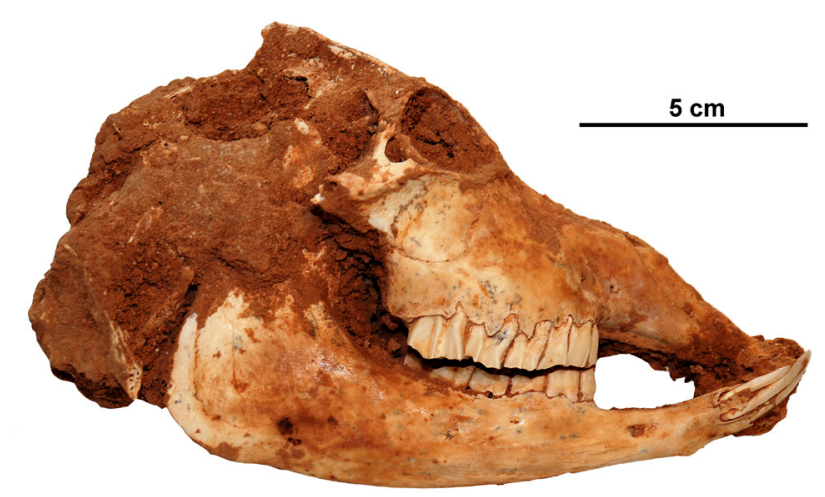

Fig. 8. Skull and mandibles of the Myotragus articulated skeleton (IMEDEA 103003) found in the Sala del Col-lapse. Three incisors can be observed in the mandible (Photo: M.A. Perelló).

Although the shape of the incisors in the different Myotragus species can depend on the wear stage of these teeth, the most mesial incisor of the most recent species, $M$. batei and $M$. balearicus, is generally a highly hypsodont evergrowing incisor (i.e., with open root) and very wide mesio-distally. The root of this tooth can be proximally located beyond the diastema, under the premolar series, and can produce a strong deformation of the lingual part of the mandibular body. $M$. pepgonellae, $M$. antiquus and $M$. kopperi display hypsodont incisors, but in a lesser degree than the most recent species, with closed roots and they are not as wide mesiodistally. The basis of the root of the incisors is never located beyond the diastema in the available material of these species.

In the case of the mandibles of Myotragus obtained from CPV, all of them display three alveoli for incisors, and the mandibles of the partial skeleton from the Sala des Col-lapse display three incisors each (Fig. 8). Their morphology, especially in the medial incisor, resembles the one of $M$. antiquus and $M$. kopperi, i.e., not extremely hypsodont, and not wide mesiodistally, none of the incisors of the mandibles from CPV extends beyond the diastema, their roots are closed, and the distal incisor (or its alveolus) is greater than the $M$. batei distal incisor (the one that is posteriorly lost in adult stages).

All these observations limit the analysis of the attribution of the CPV Myotragus to the species $M$. antiquus or $M$. kopperi. In order to establish a more accurate taxonomy of the CPV Myotragus, a further analysis of the mandibles and teeth was performed.

\begin{tabular}{|c|c|c|c|}
\hline SPECIES & $\mathrm{i} / \mathrm{c}$ & p2 & p3 \\
\hline M. palomboi & $4 ?$ & & \\
\hline M. pepgonellae & 4 & & \\
\hline M. antiquus & 3 & & \\
\hline M. kopperi & 3 & & \\
\hline M. batei & 2 & & \\
\hline M. balearicus & 1 & & \\
\hline
\end{tabular}

Fig. 9. Number of incisiforms (i.e., incisors and canine) and lower premolar size in the described Myotragus species from Mallorca, in adult stage. Black, present (normal); Dark gray: slightly reduced; Light gray: extremely reduced; White: absent. The specimens from CPV display three incisors and a slightly recuced $\mathrm{p} 3$, as $M$. kopperi.
As mentioned above, in the evolution of the Myotragus lineage a progressive reduction of size and number of premolars have been identified (Alcover et al., 1981). M. palomboi, as other caprines, displayed a slightly reduced p2 (Bover et al., 2010a), and although no other lower premolars for this species are available, it is reasonable to assume that displayed a dentition similar to other mainland caprines (i.e., fully developed premolars). M. pepgonellae already displayed an important reduction of the p2, although present (Moyà-Solà \& Pons-Moyà, 1982), whereas in $M$. antiquus and $M$. kopperi this teeth is already lost (Pons-Moyà, 1977; Moyà-Solà \& Pons-Moyà, 1981). In these two latter species, the p3 is gradually reduced (Fig. 9 and 10 C). M. batei displays an extremely reduced p3 (Crusafont \& Angel, 1966), and in the more recent species $M$. balearicus, this tooth has completely disappeared (Bate, 1909).

The scatter plots of the proportions of p3 (Lp3/Wp3, Fig. $10 \mathrm{~A})$ and the relative length of this tooth (Ltr/ Lp3, Fig. 10 B) suggest that the development of this premolar in the Myotragus from CPV falls in the range of variability of $M$. kopperi, especially in the case of Lp3/Wp3. In the case of Ltr/Lp3, the two mandibles measured from CPV show a slightly more developed p3 than M. kopperi, but as it happens in this latter species, some individuals display particularly long p3. This characteristic can be observed both in the specimen of $M$. kopperi from Pedrera de s'Ònix IMEDEA 57665 (Fig. 10 C.2), and in the Myotragus mandible from CPV IMEDEA 90462 (Fig. 10 C.3), in which the size of $\mathrm{p} 3$ is slightly longer than other specimens from the same taxa collected in the same deposits. Nevertheless, these differences could to be related to a greater wear of this tooth observed in older indiviuals, as the p3 is slightly wider and longer in the base of the tooth than in the tip. For all these reasons, the Myotragus from CPV is here attributed to M. aff. kopperi.

\section{ANCIENT DNA}

One sample from CPV (IMEDEA 91480, second upper molar) was used to test for potential contaminating DNA introduced during ancient DNA (aDNA) extraction protocols at the ACAD. The obtained material from CPV was preserved inside the cave from at least 2 My (see below) until the excavation in 2010, free of contamination from other introduced species in Mallorca, and with a putative chronology far beyond the theoretical survival of DNA in ancient samples (e.g., Willerslev \& Cooper, 2005). Thus, the sample used was considered to be an adequate negative control for aDNA extractions of Myotragus balearicus bones.

The ACAD has a dedicated laboratory on aDNA geographically separated by around $1.5 \mathrm{~km}$ from PCR and postPCR laboratories. The extraction method and PCR (Polymerase Chain Reaction) set up parameters have been published elsewhere (e.g., Austin et al., 2013; Brotherton et al., 2013). Briefly, $0.26 \mathrm{~g}$ of tooth powder were incubated overnight under constant rotation at $55^{\circ} \mathrm{C}$ in a lysis buffer of $0.5 \mathrm{M}$ EDTA, $\mathrm{pH}$ $8.0 ; 10 \% \mathrm{SDS}$; and $20 \mathrm{mg} / \mathrm{ml}$ proteinase $\mathrm{K}$. DNA 
was extracted using a silica-based suspension and and in-house binding buffer method (Brotherton et al., 2013). Universal primers for mammalian mitochondrial DNA 12S gene (Mamm 12S E Forward: 5' CTATAATCGATAAACCCCGATA 3' and Mammal 12S H Reverse: 5' GCTACACCTTGACCTAAC 3', amplifying a fragment of $96 \mathrm{bp}$, and Mammal 12S N Forward : 5' CAGCAAACCCTAAAAAGG 3' and Mammal 12S H Reverse, see above, amplifying a fragment of $34 \mathrm{bp}$ ). These primers were successful in the amplification of Myotragus balearicus DNA from Holocene samples as well as contaminating DNA from species as cow (Bos taurus), pig (Sus scrofa), sheep (Ovis aries), goat (Capra hircus) and dog (Canis familiaris) in other $M$. balearicus samples (pers. obs.).

Two microlitres of extract were used to amplify, together with an extraction control and negative PCR control, in a $25 \mu \mathrm{l}$ PCR containing: $1 \times$ Platinum
Taq High Fidelity Buffer (Invitrogen), $2 \mathrm{mM} \mathrm{MgSO}$, $0.4 \mu \mathrm{M}$ each primer, $0.25 \mathrm{mM}$ each dNTP, $0.5 \mathrm{U}$ Platinum Taq HiFi (Invitrogen), $1 \mathrm{mg} / \mathrm{ml}$ RSA (SigmaAldrich) and sterile $\mathrm{H}_{2} \mathrm{O}$. PCR cycling conditions were: initial denaturation at $94^{\circ} \mathrm{C}$ for $2 \mathrm{~min} ; 50$ cycles of denaturation at $94^{\circ} \mathrm{C}$ for $20 \mathrm{~s}$; primer annealing at $55^{\circ} \mathrm{C}$ for $15 \mathrm{~s}$; elongation at $68^{\circ} \mathrm{C}$ for $30 \mathrm{~s}$; a final elongation step at $68^{\circ} \mathrm{C}$ for $10 \mathrm{~min}$. PCR products were visualized under UV light on a $3.5 \%$ agarose gel posteriorly stained with Gel-Red (Jomar Bioscience).

As expected, the PCRs of the CPV sample failed, confirming that the extraction protocol used with the Myotragus samples did not introduce detectable amounts of contaminating DNA. The possible sources of DNA contamination detected in some samples should be then related to other agents in the deposits (e.g., soil, or other species living in the same cave, etc.) or even to $\mathrm{PCR}$ reagents.
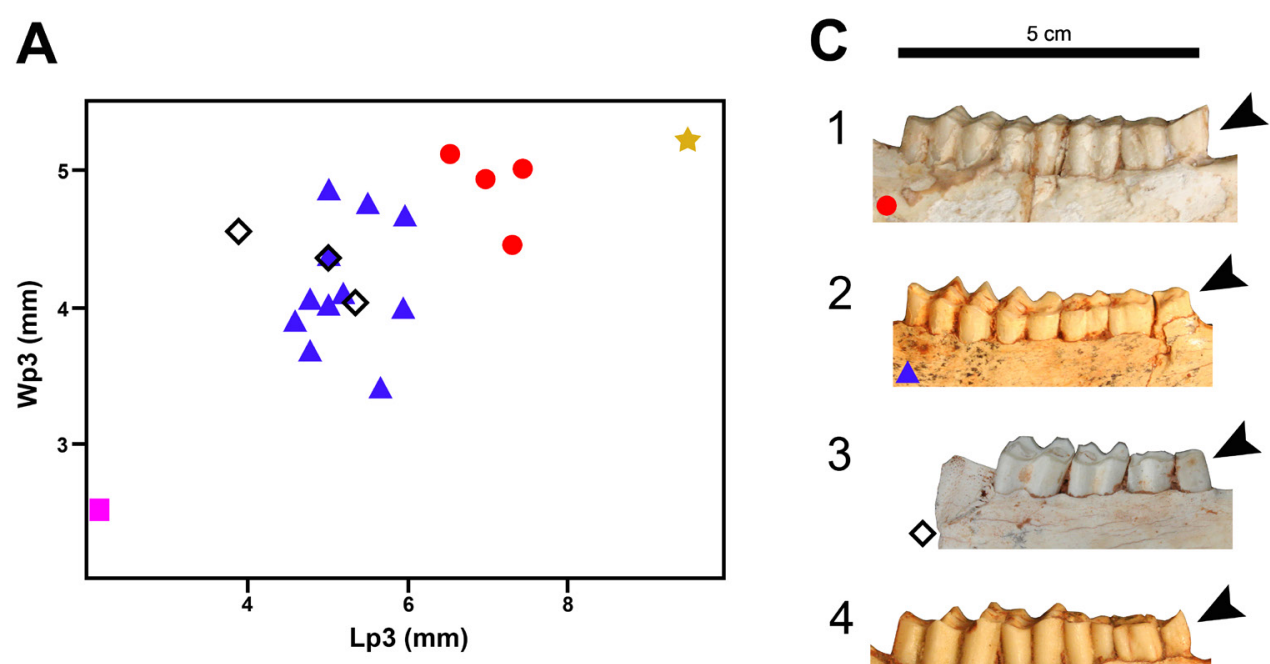

B
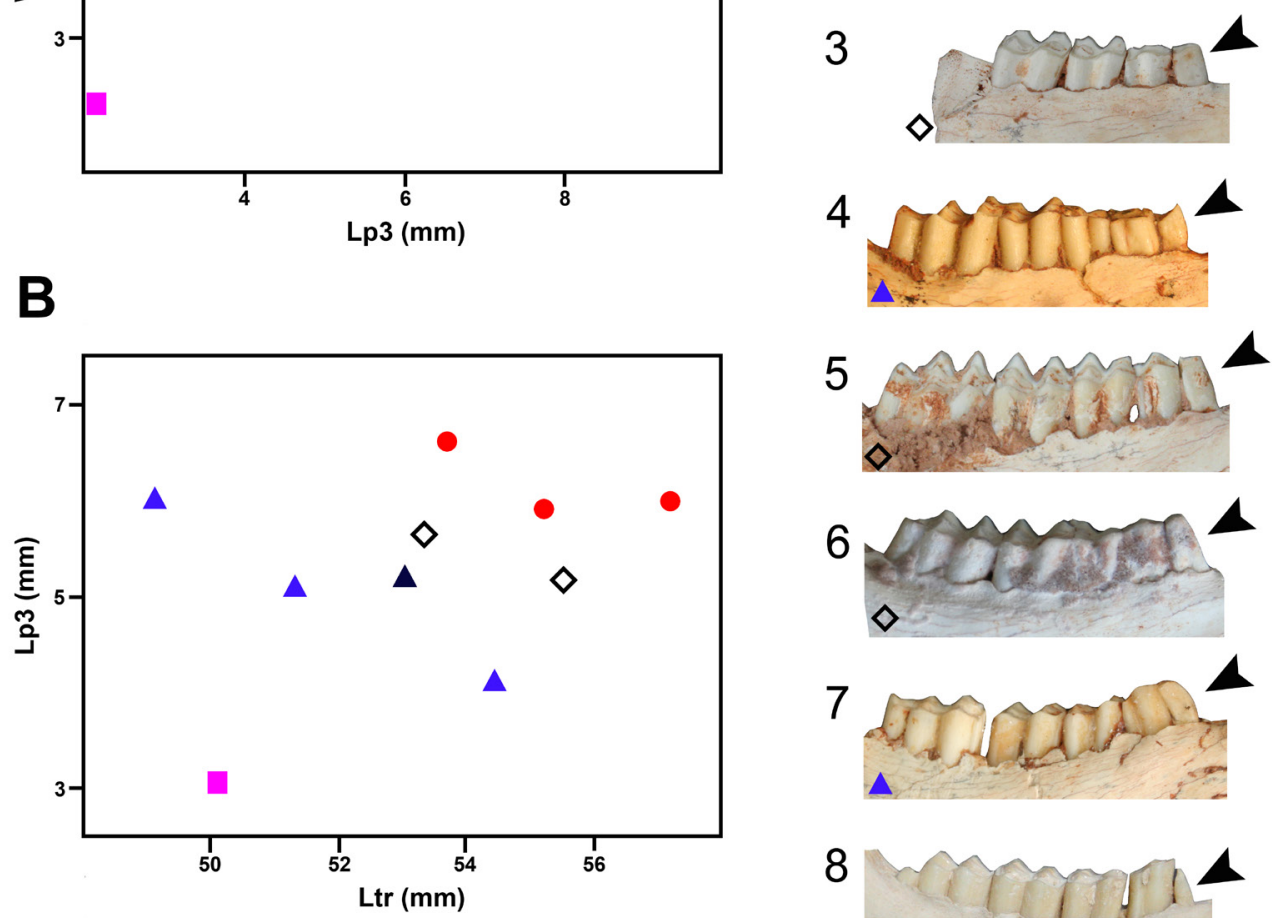

8

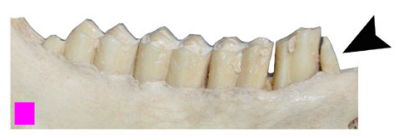

Fig. 10. Scatter plot and comparison of Myotragus teeth. A: Scatter plot of width (Wp3) versus length of p3 (Lp3) (measurements taken at $1 \mathrm{~cm}$ from the base of the tooth. Data for M. batei, M. kopperi and M. antiquus from Moyà-Solà \& Pons-Moyà, 1981. Data for M. pepgonellae obtained from Moyà-Solà \& Pons-Moyà, 1982. Used specimens from CPV are IMEDEA 90451, 90454 and 103003; B: Scatter plot of length of p3 (Lp3) versus length of tooth row (Ltr) (measurements taken at the base of the tooth). Used specimens from CPV are IMEDEA 90451, 90452 and 90454; C: Labial view of Myotragus mandibles to compare the size of the p3 in the different species. 1: $M$. antiquus IMEDEA 59245, left, reversed; 2: $M$. kopperi IMEDEA 57665, right; 3: CPV IMEDEA 90462, left, reversed; 4: M. kopperi IMEDEA 57325, right; 5: CPV IMEDEA 90454, left, reversed; 6: CPV IMEDEA 90451, right; 7: M. kopperi Holotype IMEDEA 57320, left, reversed; 8: M. batei Holotype, curated at MNIB-SHNB, right. Arrows indicate the $\mathrm{p} 3$ tooth. 
CONCLUSIONS

The similarity of the mammalian taxa from CPV to the species recorded in the Pedrera de s'Ònix deposit sheds some light to the chronology of the deposit and the geomorphic processes involved in the development of the cave. As explained above, Myotragus from CPV has a morphotype similar to M. kopperi, Hypnomys to $H$. onicensis and Nesiotites to $N$. aff. ponsi from Pedrera de s'Ònix. Regarding the birds, although there are some differences between these two deposits, up to 14 of the 18 bird taxa identified in CPV were also recorded in the Pedrera de s'Ònix deposit. In Mallorca, the amphibian genus Discoglossus has been only found in CPV and in Pedrera de s'Ònix, and the size of the lizard Podarcis from CPV agrees with the size of the Podarcis remains obtained from Pedrera de s'Ònix. Thus, it seems appropriate to consider CPV as a paleontological deposit from the Early Pleistocene, with a close chronology to Pedrera de s'Ònix.

Paleomagnetic analyses carried out in a Mallorcan cave with a remarkable stratigraphical record, Cova de Canet, furnished a date of 2.6 My for the stratigraphical levels (level J) containing $M$. antiquus and 2.4 My for the level (level E) containing Myotragus sp. according to Pons-Moyà et al. (1979), but it was later identified as a morphotype slightly more primitive than the type of $M$. kopperi, and consequently considered $M$. aff. kopperi (Alcover et al., 1981). The ratio Ltr/Lp3 (Fig. 10.B) indicates that the CPV Myotragus would be similar to this $M$. aff. kopperi from Cova de Canet. This paleomagnetic data allow us to narrow the deposition period of the fossil material at around 2.4 My ago. In this sense, the absence of more modern species of Myotragus in the deposit suggests that the collapse of the original and natural entrance to the cave was a quick event and caused the total sealing of the Galeria del Tragus/Sala del Collapse in a moment later than 2.4 My ago, trapping both the bone remains and the living animals that eventually were inside the cave at that moment. The presence of an adult Myotragus articulated skeleton (Sala del Col-lapse), and other two associated juvenile skeletons (Galeria del Tragus), agrees with the hypothesis of an original open entrance close to the deposit, and seems to indicate a limited horizontal transport of the bones inside the cave. This observation agrees with the scenario shown by the stratigraphical analyisis of the sediments in Galeria des Tragus (Fornós et al., 2010b). In general, the sediment sequence observed at the Galeria del Tragus of CPV is formed by sands and mud-silts that can be considered allochthonous (entrance facies). This characteristic seems to corroborate the existence of an ancient cave entrance through which sand deposits first, and then sediments infiltrated by surface runoff, entered the cave until the likely closing of it after the collapse of this former entry. The absence of clear lamination and flow structures in the sand deposits of aeolian origin suggest a ramp-type deposition favored by gravity. Nevertheless, the sub-horizontal location of these deposits some hundreds of meters along the gallery seems to indicate a deposition of the whole stratigraphic set in a low dynamic aquatic environment.
The finding of some skeletons and other remains of terrestrial mammals in sites located far from the putative former entrance could provide information about other currently closed entrances or fissures. The case of the skeletons of Hypnomys in Llac de na Gemma, Sector F, and Sector de Gregal (Fig. 6 B-D) could be explained both by the existence of former entrances or, more probably, small fissures nearby that could be used by this small mammal to entry the cave. More intriguing is the presence of Myotragus bones in the Sala Que No Té Nom and specially the case of the articulated skeleton in the upper maze (Fig. 6 A). In several Mallorcan caves, Myotragus individuals have been found far away from the current entrance on the cave, indicating that the species was going relatively deep into caves (e.g., Cova des Penyal Blanc; Alcover et al., 1997, or Cova Genovesa; Gràcia et al., 2003). But the important distance from the former entrance, located at the Sala del Col-lapse, and the location of those Myotragus, together with the labyrinthine galleries beyond the Galeria del Tragus, seems to indicate the presence of other entrances currently collapsed.

Although an important number of Mallorcan caves containing Pliocene and Quaternary fossils has been already recorded (Bover \& Alcover, 2005), the presence of paleontological remains of Myotragus is relatively frequent in coastal caves below the current water-table, as the Cova Genovesa (Gràcia et al., 2003) or in air-filled passages, as CPV. In the case of deposits older than Middle Pleistocene, they are mainly hard breccias in fossil caves, and the state of preservation of the bones is usually poor. For this reason, the finding of the fossil material in CPV, with a chronology around $2.4 \mathrm{My}$, or even older, and in this exceptional preservation state, is outstanding. The material obtained is being currently studied (e.g., Jordana et al., 2013) and it will surely improve our understanding, in a near future, of several aspects of the taxonomy, evolution and morphology of the species found in CPV.

The geochronological data supplied by the paleontologic deposit from Galeria del Tragus is quite determinant regarding the minimum age of speleogenesis that could be postulated for CPV (Ginés et al., 2014). In this respect, the main cave-formation phases must correspond at least to mid-Pliocene times, with a later sea-controlled complex evolution happened along the whole Quaternary.

\section{ACKNOWLEDGEMENTS}

The excavation was possible thanks to the help and effort of a large group of cavers from the Balearic Federation of Speleology (FBE). The leaders of this group, Guillem Mulet, Antoni Mulet, Anders Kristofersson, Antoni Croix and Manolo Luque, provided assistance and guidance inside the cave, general preparation of the excavation, carriage of equipment, food, and, other material to the deposit some weeks prior to excavation, and they organized the group of volunteers. These volunteers carried most of the equipment to the deposit and they 
entried the second and third days of the excavation campaign to carry the excavated material to outside the cave. Thanks are due to all of them.

Enric Alcover (Palma) and Carl Mehling (New York) were part of the excavation team, and they highly contributed to the success of the campaign. Bernat Font (Sant Llorenç, Mallorca) restored an important part of the collected material.

We are thankful to Helena Inglada for her encouragement and help with the paperwork to request official permits and financial support to the Consell de Mallorca. Thanks are also due to Francesc Ruiz for his help in the search for sponsors.

Graphic documentation of the excavation was made by Miquel Àngel Perelló and Miquel Vives. Thanks are also due to M.A. Perelló and G. Mulet for the permission to publish the photos in figures 2, 6.B and 8, and 6.C, respectively.

Miguel Ángel Soriano and Juan Miguel Aparicio from Servicios Sociosanitarios Generales (ssg) provided paramedical assistance during the excavation.

Dr. Bastien Llamas (Adelaide) made some important suggestions for the DNA extraction procedure of the Myotragus bone sample. Prof. Alan Cooper (Adelaide) reviewed the aDNA part of the manuscript.

Consell de Mallorca (Mallorcan Government) provided financial resources to build the bridge over the most delicate sector of the Galeria del Tragus. We are also thankful to the Direcció General de Biodiversitat from the Balearic Government, and specially to Margalida Femenia, for the permit to carry out the excavation in the Cova des Pas de Vallgornera.

The companies Oxidoc, Es Refugi, and Foracorda provided some equipment for the excavation team. Other miscellaneous support was provided by Protección Civil España, Consejo Superior de Deportes, and Federación Española de Espeleología.

One of the authors, $\mathrm{PB}$, received support from a JAE-DOC (CSIC) contract (Junta para la Ampliación de Estudios) and from the a Marie Curie IOF, and JR has a "Juan de la Cierva" postdoctoral Research Fellowship (JCI-2010-06148) of the Ministerio de Economia y Competitividad of Spain. Part of this work has received financial support from MINECOFEDER under grants.

This paper is included in the Research Projects CGL2012-38087 (Dirección General de Investigación Cientifica y Técnica of the Spanish Ministerio de Economía y Competitividad), CGL201238434-C03-01, GIU12/35 (University of the Basque Country UPV/EHU), and CGL2010-18616. Part of this research was also supported by a Marie Curie International Outgoing Fellowship within the 7th European Community Framework Programme (project MEDITADNA, PIOF-GA-2011-300854, FP7PEOPLE).

\section{REFERENCES}

Agustí J., 1980 - Hypnomys eliomyoides nov. sp. nuevo glírido (Rodentia, Mammalia) del Pleistoceno de Menorca. Endins, 7: 49-52.
Agustí J., Bover P. \& Alcover J.A., 2012 - A new genus of endemic cricetid (Mammalia, Rodentia) from the late Neogene of Mallorca (Balearic Islands, Spain). Journal of Vertebrate Paleontology, 32: 722-726. http://dx.doi.org/10.1080/02724634.2012.652322

Alcover J.A., Moyà-Solà S. \& Pons-Moyà J., 1981 - Les Quimeres del Passat. Els Vertebrats Fòssils del PlioQuaternari de les Balears $i$ Pitiüses. Monografies Científiques, Editorial Moll, Palma, 260 p.

Alcover J.A., Font A. \& Trias M., 1997 - Primera troballa de fauna vertebrada plistocènica a Cabrera. Endins, 21: 79-82.

Austin J., Soubrier J., Prevosti F.J., Prates L., Trejo V., Mena F. \& Cooper A., 2013 - The origins of the enigmatic Falkland Islands wolf. Nature Communications, 4: 1552. http://dx.doi.org/10.1038/ncomms2570

Bailon S., Bover P., Quintana J. \& Alcover J.A., 2010 - First fossil record of Vipera Laurenti 1768 "Oriental vipers complex" (Serpentes: Viperidae) from the Early Pliocene of the Western Mediterranean Islands. Comptes Rendus Palevol, 9: 147-154. http://dx.doi.org/10.1016/j.crpv.2010.04.001

Bailon S., Boistel R., Bover P. \& Alcover J.A., 2014 Maioricalacerta rafelinensis gen. et sp. nov (Squamata, Lacertidae) from the Early Pliocene of Mallorca (Balearic Islands, Western Mediterranean Sea). Journal of Vertebrate Paleontology, 34 (2): 318-326.

Bate D.M.A., 1909 - Preliminary note on a new artiodactyle from Mallorca Myotragus balearicus, gen. et sp. nov. Geological Magazine, 6: 385-389. http://dx.doi.org/10.1017/S0016756800124665

Bate D.M.A., 1918 - On a new genus of extinct muscardine rodent from the Balearic Islands. Proceedings of the Zoological Society London, 88: 209-222

http://dx.doi.org/10.1111/j.1096-3642.1918.tb02091.x

Bate D.M.A., 1944 - Pleistocene shrews from the larger Western Mediterranean Islands. The Annals and Magazine of the Natural History Series, 11: 738-769.

Bover P. \& Alcover J.A., 1999 - The evolution and ontogeny of the dentition of Myotragus balearicus Bate 1909 (Artiodactyla: Caprinae): evidences from new fossil data. Biological Journal of the Linnean Society, 68: 401-428. http://dx.doi.org/10.1111/j.1095-8312.1999.tb01178.x

Bover P. \& Alcover J.A., 2005 - Catàleg de jaciments amb Myotragus a les Illes Balears. In: Alcover J.A. \& Bover P. (Eds.), Proceedings of the International Symposium "Insular Vertebrate Evolution: the Palaeontological Approach". Monografies de la Societat d'Història Natural de les Balears, 12: 51-58.

Bover P. \& Tolosa F., 2005 - The olfactory ability of Myotragus balearicus: preliminary notes. In: Alcover J.A. \& Bover P. (Eds.), Proceedings of the International Symposium "Insular Vertebrate Evolution: the Palaeontological Approach”. Monografies de la Societat d'Història Natural de les Balears, 12: 85-94.

Bover P., Quintana J., Agustí J., Bailón S. \& Alcover J.A., 2007 - Caló den Rafelino: an Early Pliocene site in Mallorca, Western Mediterranean. In: - Abstracts del "VII Simposio Internacional de Zoología". Topes de Collantes: 119.

Bover P., Quintana J. \& Alcover J.A., 2008 - Three islands, three worlds: paleogeography and evolution of the vertebrate fauna from the Balearic Islands. Quaternary International, 182: 135-144. http://dx.doi.org/10.1016/j.quaint.2007.06.039

Bover P., Quintana J. \& Alcover J.A., 2010a- A new species of Myotragus Bate, 1909 (Artyodactyla, Caprinae) from the Early Pliocene of Mallorca (Balearic Islands, western Mediterranean). Geological Magazine, 147: 871-885. http://dx.doi.org/10.1017/S0016756810000336 
Bover P., Alcover J.A., Michaux J.J., Hautier L. \& Hutterer R., 2010b - Body shape and life style of the extinct Balearic dormouse Hypnomys (Rodentia, Gliridae): new evidence from the study of associated skeletons. PloS ONE, 5 (12): e 15817.

http://dx.doi.org/10.1371/journal.pone.0015817

Bover P., Rofes J., Bailon S., Agustí J., Cuenca-Bescós G., Torres E. \& Alcover J.A., 2014 - Late Miocene/ Early Pliocene vertebrate fauna from Mallorca (Balearic Islands, Western Mediterranean): an update. Integrative Zoology, 9: 183-196.

http://dx.doi.org/10.1111/1749-4877.12049

Brotherton P., Haak W., Templeton J., Brandt G., Soubrier J., Adler C.J., Richards S.M., Der Sarkissian C., Ganslmeier R., Friederich S., Dresely V., vanOven M., Kenyon R., Van der Hoek M.B., Korlach J., Luong K., Ho S.W.Y., QuintanaMurci L., Behar D.M., Meller H., Alt K.W., Cooper A. \& The Genographic Consortium., 2013 - Neolithic mitochondrial haplogroup H genomes and the genetic origins of Europeans. Nature Communications, 4: Art.1764.

http://dx.doi.org/10.1038/ncomms2656

Clauzon G., Suc J.P., Gautier F., Berger A. \& Loutre M.F., 1996 - Alternate interpretation of the Messinian salinity crisis: controversy resolved? Geology, 24: 363-366.

http://dx.doi.org/10.1130/0091-

7613(1996)024<0363:AIOTMS>2.3.CO;2

Collignon M., 1982 - Une première des espéléos namurois à Majorque (Espagne). Au royaume d'Hades, 2: 14-26.

Crusafont M. \& Angel B., 1966 - Un Myotragus (Mammifère Ruminant), dans le Villafranchien de l'île de Majorque: Myotragus batei, nov. sp. Comptes Rendues de l'Academie de Sciences Paris, 262: 2012-2014.

Díaz A., Bover P. \& Alcover J.A., 2014 - Fossil Vertebrate Database from Cova des Pas de Vallgornera (Llucmajor, Mallorca). International Journal of Speleology, 43 (2): 227-230.

http://dx.doi.org/10.5038/1827-806X.43.2.10

Dodelin B., 2002 - Identification des Chiroptères de France à partir des restes osseux. Fédération Française de Spéléologie, La Ravoire, 48 p.

Dorale J.A., Onac B.P., Fornós J.J., Ginés J., Ginés A., Tuccimei P. \& Peate D.W., 2010 - Sea-level highstand 81,000 years ago in Mallorca. Science, 327: 860-863. http://dx.doi.org/10.1126/science.1181725

Encinas J.A., 2006 - Relación inventarial de subterráneos naturales de las Illes Balears, año 2006. Ediciones JAES, Colección Tarsilbet, Pollença, 236p.

Encinas J.A. \& Alcover J.A., 1997 - El jaciment fossilifer de la Cova Estreta (Pollença). Endins, 21: 83-92.

Felten H., Helfricht A. \& Storch G., 1973 - Die Bestimmung der Europäischen Fledermäuse nach der distalen Epiphyse des Humerus. Senckenbergiana biol., 54: 291-297.

Fornós J.J. \& Gelabert B., 2004 - Baleares. In: Vera J.A. (Ed.), Geología de España. Madrid: Sociedad Geológica de España, Instituto Geológico y Minero de España: 450-464.

Fornós J.J., Pomar L. \& Ramos E., 2002 - Tertiary: Balearic Islands. In: Gibbons W. \& Moreno T. (Eds.), The Geology of Spain. Geological Society of London: 327-334.

Fornós J.J., Ginés A., Ginés J., Gràcia F., Merino A., Cifre J. \& Hierro F., 2010a - Hypogene speleogenetic evidences in the development of Cova des Pas de Vallgornera (Mallorca Island, western Mediterranean). In: Andreo B., Carrasco F., Durán J.J. \& Lamoreaux J.W. (Eds.), Advances in research in karst media. Berlin: Environmental Earth Sciences Series SpringerVerlag: 349-354.

http://dx.doi.org/10.1007/978-3-642-12486-0 54
Fornós J.J., Ginés J., Merino A. \& Bover P., 2010b - El rebliment sedimentari de la galeria del Tragus a la cova des Pas de Vallgornera (Llucmajor, Mallorca). Bolletí de la Societat d'Història Natural de les Balears, 53: 179-192.

Fornós J.J., Merino A., Ginés J., Ginés A. \& Gràcia F., 2011 - Solutional features and cave deposits related to hypogene speleogenetic processes in a littoral cave of Mallorca Island (western Mediterranean). Carbonates and Evaporites, 26: 69-81.

http://dx.doi.org/10.1007/s13146-010-0040-3

Fornós J.J., Ginés J., Gràcia F., Merino A., Gómez-Pujol L. \& Bover P., 2014 - Cave deposits and sedimentary processes in Cova des Pas de Vallgornera (Mallorca, Western Mediterranean). International Journal of Speleology, 43 (2): 159-174.

http://dx.doi.org/10.5038/1827-806X.43.2.5

Furió M. \& Pons-Monjo G., 2013 - The use of the species concept in paleontology. Comment on "Nesiotites rafelinensis sp. nov., the earliest shrew (Mammalia, Soricidae) from the Balearic Islands, Spain" by Rofes et al., 2012. Palaeontologia Electronica, 16: 16A.

Gábor C., 2008 - Taxonomy of the Horseshoe Bats of the World (Chiroptera, Rhinolophidae). PhD Dissertation, University of Debrecen, Hungary: 178 p.

Gautier F., Clauzon G., Suc J.P., Cravatte J. \& Violantini D., 1994 - Âge et durée de la crise de salinité messinienne. Comptes Rendus de l'Académie des Sciences Naturelles de Paris, Serie II, 318: 1103-1109.

Gibbard P.L., Head M.J., Walker M.J.C. \& The Subcomission on Quaternary Stratigraphy., 2010 Formal ratification of the Quaternary System/Period and the Pleistocene Series/Epoch with a base at 2.58 Ma. Journal of Quaternary Science, 25: 96-102. http://dx.doi.org/10.1002/jqs.1338

Ginés J., Ginés A., Fornós J.J., Gràcia F. \& Merino A., 2008 - Noves observacions sobre l'espeleogènesi en el Migjorn de Mallorca: els condicionants litològics en alguns grans sistemes subterranis litorals. Endins, 32: 49-79.

Ginés J., Ginés A., Fornés J.J., Merino A. \& Gràcia F., 2009a- On the role of hypogene speleogenesis in shaping the coastal endokarst of southern Mallorca (western Mediterranean). In: Klimchouk A.B. \& Ford D.C. (Eds.), Hypogene speleogenesis and karst hydrogeology of artesian basins. Special paper 1. Simferopol: Ukrainian Institute of Speleology and Karstology: 91-99.

Ginés J., Ginés A., Fornós J.J., Merino A. \& Gràcia F., 2009b - About the genesis of an exceptional coastal cave from Mallorca island (Western Mediterranean). The lithological control over the pattern and morphology of Cova des Pas de Vallgornera. In: White W.B. (Ed.), Proceedings of the $15^{\text {th }}$ International Congress of Speleology. Kerrville: International Union of Speleology: (1) 481-487.

Ginés J., Fornós J.J., Ginés A., Merino, A. \& Gràcia F., 2014 - Geologic constraints and speleogenesis of Cova des Pas de Vallgornera, a complex coastal cave from Mallorca Island (Western Mediterranean). International Journal of Speleology, 43 (2): 105-124. http://dx.doi.org/10.5038/1827-806X.43.2.2

Gràcia F., Jaume D., Ramis D., Fornós J.J., Bover P., Clamor B., Gual M.A. \& Vadell M., 2003 - Les coves de Cala Anguila (Manacor, Mallorca). II: la cova Genovesa o cova d'en Bessó. Espeleogènesi, geomorfologia, hidrologia, sedimentologia, fauna, paleontologia, arqueologia i conservació. Endins, 25: 43-86.

Gràcia F., Fornós J.J., Gamundí P., Clamor B., Pocoví J. \& Perelló M.A., 2009 - Les descobertes subaquàtiques a la Cova des Pas de Vallgornera (Llucmajor, Mallorca): història i descripció dels descobriments, hidrologia, espeleotemes, sediments, paleontologia i fauna. Endins, 33: 35-72. 
Guerra C., Bover P. \& Alcover J.A., 2012 - A new species of extinct little owl from the Pleistocene of Mallorca (Balearic Islands). Journal of Ornithology, 152: 347354. http://dx.doi.org/10.1007/s10336-011-0749-3

Gunnell G.F., Eiting T.P. \& Geraads D., 2011 - New late Pliocene bats (Chiroptera) from Ahl al Oughlam, Morocco. Neues Jahrbuch für Geologie und Paläontologie, 260: 55-71. http://dx.doi.org/10.1127/0077-7749/2011/0128

Hammer Ø., Harper D.A.T. \& Ryan P.D., 2001 PAST: Paleontological Statistics Software Package for Education and Data Analysis. Version 2.01. Palaeontologia Electronica, 4: art.4, 9pp.

Jordana X. \& Köhler M., 2011 - Enamel microstructure in the fossil bovid Myotragus balearicus (Majorca, Spain): implications for life-history evolution of dwarf mammals in insular ecosystems. Palaeogeography, Palaeoclimatology, Palaeoecology, 300: 59-66. http://dx.doi.org/10.1016/j.palaeo.2010.12.008

Jordana X., Marín-Moratalla N., Moncunill-Solé B., Bover P., Alcover J.A. \& Köhler M., 2013 - First fossil evidence for the advance of replacement teeth coupled with life history evolution along an anagenetic mammalian lineage. PLoS ONE, 8: e70743. http://dx.doi.org/10.1371/journal.pone.0070743

Köhler M. \& Moyà-Solà S., 2004 - Reduction of brain and sense organs in the fossil insular bovid Myotragus. Brain, Behavior and Evolution, 63: 125-140. http://dx.doi.org/10.1159/000076239

Köhler M. \& Moyà-Solà S., 2009 - Physiological and life history strategies of a fossil large mammal in a resourcelimited environment. Proceedings of the National Academy of Science USA, 106: 20354-20358.

http://dx.doi.org/10.1073/pnas.0813385106

Kotsakis T., 1981 - Le Lucertole (Lacertidae, Squamata) del Pliocene, Pleistocene e Olocene delle Baleari. Bolletí de la Societat d'Història Natural de les Balears, 25: 135-150.

Krijgsman W., Hilgen F.J., Raffi I., Sierro F.J. \& Wilson D.S., 1999 - Chronology, causes and prograssion of the Messinian salinity crisis. Nature, 400: 652-655. http://dx.doi.org/10.1038/23231

Lindenau C., 2005 - Middle Pleistocene bats (Mammalia: Chiroptera) from the Yarimburgaz Cave in Turkish Thrace (Turkey). Eiszeitalter und Gegenwart, 55: 122-148.

Merino A., 1993 - La Cova des Pas de Vallgornera. Endins, 19: 17-23.

Merino A., 2000 - Nuevas extensiones de la Cova des Pas de Vallgornera (Llucmajor, Mallorca). Endins, 23: 7-21.

Merino A. \& Fornós J.J., 2010 - Los conjuntos morfológicos de flujo ascendente (morphologic suite of rising flow) en la Cova des Pas de Vallgornera (Llucmajor, Mallorca). Endins, 34: 85-100.

Merino A., Mulet A. \& Mulet G., 2006 - La cova des Pas de Vallgornera: 23 kilómetros de desarrollo topografiado (Llucmajor, Mallorca). Endins, 30: 29-48.

Merino A., Mulet A., Mulet G., Croix A. \& Gràcia F., 2007 - La cova des Pas de Vallgornera (Llucmajor, Mallorca): 40 kilómetros de desarrollo topografiado. Endins, 31: 101-110.

Merino A., Mulet A., Mulet G., Croix A. \& Gràcia F., 2008 - La cova des Pas de Vallgornera (Llucmajor, Mallorca): alcanza los 55 kilómetros de desarrollo topográfico. Endins, 32: 33-42.

Merino A., Mulet A., Mulet G., Croix A. \& Gràcia F., 2009 - Cova des Pas de Vallgornera: an exceptional littoral cave from Mallorca island (Spain). In: White W.B. (Ed.), Proceedings of the $15^{\text {th }}$ International Congress of Speleology. Kerrville: International Union of Speleology: (1) 522-527.

Merino A., Mulet A., Mulet G., Croix A., Kristofersson A., Gràcia F., Ginés J. \& Fornós J.J., 2011 - La cova des Pas de Vallgornera (Llucmajor, Mallorca). La cavitat de major desenvolupament de les Illes Balears. Endins, 35/Monografies de la Societat d'Història Natural de les Balears, 17: 147-164.
Merino A., Mulet A., Mulet G., Croix A., Kristofersson A., Gràcia F. \& Perelló M.A., 2014 - Cova des Pas de Vallgornera, (Mallorca, Spain): history of exploration and cave description. International Journal of Speleology, 43 (2): 95-104.

http://dx.doi.org/ 10.5038/1827-806X.43.2.1

Mills D.H., 1976 - Osteological study of the Pleistocene dormouse Hypnomys morpheus Bate from Mallorca (Rodentia, Gliridae). Publications from the Palaeontological Institution of the University of Uppsala, Special Volume, 4: 1-58.

Mourer-Chauviré C., Moyà-Solà S. \& Adrover R., 1977 Les oiseaux des gisements quaternaires de Majorque. Nouvelles Archives du Muséun d'Histoire Naturelle de Lyon, 15: 61-64.

Mourer-Chauviré C., Alcover J.A., Moyà-Solà S. \& PonsMoyà J., 1980 - Une nouvelle forme insulaire d'effraie géante, Tyto balearica n. sp., (Aves, Strigiformes), du Plio-Pléistocene des Baléares. Geobios, 13: 803-811. http://dx.doi.org/10.1016/S0016-6995(80)80060-X

Moyà-Solà S. \& Pons-Moyà J., 1981 - Myotragus kopperi, une nouvelle espèce de Myotragus Bate, 1909 (Mammalia, Artiodactyla, Rupicaprini). Proceedings of the Koninklijke Nederlandse Akademie van Wetenschappen, Ser. B, 84: 57-6.

Moyà-Solà S. \& Pons-Moyà J., 1982 - Myotragus pepgonellae nov. sp. un primitivo representante del género Myotragus Bate, 1909 (Bovidae, Mammalia) en la isla de Mallorca (Baleares). Acta Geológica Hispánica, 17: 77-87.

Pomar L., Ward W.C. \& Green D.G., 1996 - Upper Miocene reef complex of the Llucmajor area, Mallorca, Spain. In: Franseen E., Esteban M., Ward W.C. \& Rouchy J.M. (Eds.), Models for carbonate stratigraphy from Miocene reef complexes of the Mediterranean regions. SEPM Concepts in Sedimentology and Paleontology, 5: 191-225.

Pons-Monjo G., Furió M. \& Moyà-Solà S., 2010 - The genus Nesiotites (Soricidae, Insectivora, Mammalia) in the Balearic Islands: state of the art. Cidaris, 30: 253-258.

Pons-Monjo G., Moyà-Solà S. \& Furió M., 2012 - New data on the origin of Nesiotites (Soricidae, Mammalia) in Menorca (Balearic Islands, Spain). Comptes Rendus Palevol, 11: 393-401.

http://dx.doi.org/10.1016/j.crpv.2012.03.001

Pons-Moyà J., 1977 - La nouvelle espèce Myotragus antiquus de l'île de Majorque (Baléares). Proceedings of the Koninklijke Nederlandse Akademie van Wetenschappen, Ser. B, 80: 215-221.

Pons-Moyà J. \& Moyà-Solà S., 1980 - Nuevo representante del género Nesiotites Bate, 1944; Nesiotites meloussae nov. sp. (Insectivora. Soricidae) de los rellenos cársticos del Barranc de Binigaus (Es Mercadal, Menorca). Endins, 7: 53-56.

Pons-Moyà J., Moyà-Solà S. \& Kopper S., 1979 - La fauna de mamíferos de Sa Cova de Canet y su cronología. Endins, 5-6: 55-58.

Popov V., 2004 - Pliocene small mammals (Mammalia, Lipotyphla, Chiroptera, Lagomorpha, Rodentia) from Muselievo (North Bulgaria). Geodiversitas, 26: 403-491.

Quintana J., Bover P., Alcover J.A., Agustí J. \& Bailon S., 2010 - Presence of Hypolagus Dice, 1917 (Mammalia, Lagomorpha) in the Neogene of the Balearic Islands (Western Mediterranean): Description of Hypolagus balearicus nov. sp. Geobios, 43: 555-567. http://dx.doi.org/10.1016/j.geobios.2010.03.003

Rabeder G., 1972 - Die Insectivoren und Chiropteren (Mammalia) aus dem Altpleistozan von Hundsheim (Niederosterreich). Annalen des Naturhistorischen Museums in Wien, 76: 375-474. 
ReumerJ.W.F., 1979 - On two new micromammals from the Pleistocene of Mallorca. Proceedings of the Koninklijke Nederlandse Akademie van Wetenschappen, Ser. B, 82: 473-482.

Reumer, J.W.F., 1980 - On the Pleistocene shrew Nesiotites hidalgo Bate 1944 from Majorca (Insectivora, Soricidae). I \& II. Proceedings of the Koninklijke Nederlandse Akademie van Wetenschappen, Ser. B, 83: 39-68.

Reumer J.W.F., 1981 - The Pleistocene mammals from Sa Pedrera de S'Onix, Majorca (Gliridae, Soricidae). Proceedings of the Koninklijke Nederlandse Akademie van Wetenschappen, Ser. B, 84: 2-11.

Reumer J.W.F., 1984 - Ruscinian and Early Pleistocene Soricidae. Geological Survey Professional Paper, 565: 1-74.

Reumer J.W.F., 1994 - Eliomys (Hypnomys) onicensis nomen novum, to replace the homonym Hypnomys intermedius Reumer, 1981 (Rodentia: Gliridae) from Majorca. Zeitschrift für Säugetierkunde, 59: 380-381.

Rofes J., Bover P., Cuenca-Bescós G. \& Alcover J.A., 2012 - Nesiotites rafelinensis $s p$. nov., the earliest shrew (Mammalia, Soricidae) from the Balearic Islands, Spain. Palaeontologia Electronica, 15: 8A.
Rofes J., Bover P., Cuenca-Bescós G. \& Alcover J.A., 2013 Proportions, characters and chronologies: their contribution to systematic paleontology. A rebuttal to Furio and PonsMonjo. Palaentologia Electronica, 16 (2): 20A.

Seguí B., 2001 - A new species of Pica (Aves: Corvidae) from the Plio-Pleistocene of Mallorca, Balearic Islands (Western Mediterranean). Geobios, 34: 339-347. http://dx.doi.org/10.1016/S0016-6995(01)80080-2

Sondaar P.Y., McMinn M., Seguí B. \& Alcover J.A., 1995 - Interès paleontològic dels jaciments càrstics de les Gimnèsies i les Pitiüses. Endins, 20/Monografies de la Societat d'Història Natural de les Balears, 3: 155-170.

Tuccimei P., Soligo M., Fornós J.J., Ginés A., Ginés J., Onac B.P. \& Villa I.M., 2009 - Precipitation of phreatic overgrowths at the water table of meteoric-marine mixing zones in coastal cave systems: a useful tool in sea level change reconstruction. In: White W.B. (Ed.), Proceedings of the $15^{\text {th }}$ International Congress of Speleology. Kerrville: International Union of Speleology: (1) 554-560.

Willerslev E. \& Cooper A., 2005 - Ancient DNA. Proceedings of the Royal Society B, 272: 3-16.

http://dx.doi.org/10.1098/rspb.2004.2813

Woloszyn B.W., 1987 - Pliocene and Pleistocene bats of Poland. Acta Palaeontologica Polonica, 32: 207-325. 